\title{
GÖYNÜKLÜ AHMED EFENDİ'NİN MECMUASI
}

\section{THE MECMUA OF GÖYNÜKLÜ AHMED EFENDI}

Hakan YILDIZ*

$\ddot{O} z$

Bazı Osmanlı ulemâsı ve devlet adamları, çeşitli konulara dair din̂̂ ve din dışı yazıları bir araya getirmek suretiyle "Mecmua" adı verilen eserler kaleme almıştır. Bu bağlamda çalışmamızda, bir XVIII. yüzyıl Osmanlı maliye bürokratı olan Göynüklü Ahmed Efendi'nin bazı notları ile din̂̂ ve din dışı çeşitli eserlerdeki yazılardan derlediğ̈i "Mecmua"sı incelenmiştir. Araştırmada, öncelikle Mecmua'nın bilinen iki nüshası olan Berlin ve Rado nüshaları tanıtılmış, daha sonra her iki nüshanın şeklîlfizikî özellikleri ve muhtevaları ortaya konulmak suretiyle mecmua tüm yönleriyle ele alınmıştır. Eserde müellif Ahmed Efendi'nin bizzat katıldı ̆̆ı ve şahsî tanıklıklarına dayanarak kaleme aldı̆̆ı Prut, Mora, Avusturya ve Iran seferlerine ait tarihî kayıtlar ise mecmuayı emsallerinden ayıran önemli bir özellik olarak ön plana çıkmaktadır. Bu kayıtlar, sözkonusu dönemler için birincil kaynak olmanın yanı sıra, çă̆daş kaynaklarda bulunmayan bazı bilgileri ihtiva etmesi sebebiyle eşsiz mahiyettedir.

\section{Anahtar Kelimeler}

Mecmua, Göynüklü Ahmed Efendi, Berlin Nüshası, Rado Nüshasl, sefer

\section{Abstract}

Some Ottoman ulemas and statesmen had been penned some texts which were named "Mecmua" on various topics as combining religious and non-religious writings. Concordantly, the Mecmua which was covering some notes and writings in the religious and non-religious works of Göynüklü Ahmed Efendi, who was a Ottoman finance bureaucrat in the 18th century, is examined in this study. In the study, firstly Berlin and Rado, which have been known copies of mecmua, are introduced, afterwards the 'mecmua' is handled by its all aspects as depicting the exoterical and physical specifications of each copy. Records, which were taken by Ahmed Efendi, the author, about the Prut, Mora, Austria and Iran campaigns, in the Mecmua, differentiate it and give prominence among its's counterparts. These records, besides being a primary source for those times, are unique as well because they involve some data which are not covered by the contemporary sources.

\section{Keywords}

Mecmua, Göynüklü Ahmed Efendi, Berlin Copy, Rado Copy, campaign

\footnotetext{
Dr. Öğr. Üyesi, Nişantaşı Üniversitesi İktisadi, İdari ve Sosyal Bilimler Fakültesi Tarih Bölümü. hakan.yildiz@nisantasi.edu.tr
} ORCID: 0000-0003-4609-5087 


\section{GİRIŞ}

İslâm kültüründe bir ya da daha fazla yazar tarafından çeşitli konulara dair dinî ve din dışı nesir, manzume ve şiir türü yazıların bir araya getirilmesiyle oluşturulmuş derlemelere, "toplanıp biriktirilmiş, tanzîm ve tertîb edilmiş şeyler" (Ş. Sâmî, 1318, s. 1293) anlaminda "Mecmua" adı verilmektedir (Uzun, 2003, s. 265). Mecmualar, şahsî bir derleme olması dolayısıyla şekil ve muhteva yönünden derleyen kişinin ilgi alanlarını ve zevkini yansitan eserlerdir. Ancak edebiyattan ilahiyata, sanattan sihre, felsefeden tıbba, folklordan etnografyaya kadar pek çok farklı konuda bilgi barındıran mecmuaların (Aydemir, 2007, s. 123; Pala, 2014, s. 300) henüz tam bir tasnifi yapılamamıştır (Kut, 1986, s. 170).

Bununla birlikte Agah Sırrı Levent, mecmuaları; nazire mecmuaları, birer antoloji niteliğinde seçme şiir mecmuaları, çeşitli konulardaki risalelerin bir araya getirilmesiyle oluşturulmuş mecmualar, aynı konulardaki eserlerin bir araya getirilmesiyle oluşturulmuş mecmualar ve ünlü kişilerce hazırlanmış, birçok faydalı bilgileri, fıkraları ve özel mektupları ihtiva eden mecmualar olmak üzere beş ana grupta toplamıştır (Levent, 1984, s. 166-167). Daha sonra Günay Kut; nazire mecmuaları, seçme şiir mecmuaları (mecmua-i eş'ar, mecmua-i devâvin), aynı konudaki eserlerin bir araya getirilmesiyle hazırlanmış mecmualar (mecmua-i edviyye, mecmua-i tevârih, mecmua-i muammeyat, mecmua-i münşeat, mecmua-i resâil), karışık yani manzum ve mensur veya farklı dillerle yazılmış parçalardan oluşan mecmualar ve derleyeni belli mecmualar (Ömer bin Mezid, Mecmu'atu'n-Neza'ir; Eğirdirli Hacı Kemal, Cami'u'n-Neza'ir; Edirneli Nazmi, Mecma'u'n-Neza'ir; Pervane Bey Mecmu'ası; Budinli Hisali, Metali'u'n-Neza'ir) başlıkları altında bu beş grubu biraz farklılıkla tekrarlamıştır (Kut, 1986, s. 170-172). Kamil Ali Gıynaş da araştırmalarında pek çok mecmua türü tespit etmiştir. ${ }^{1}$

Osmanlı ulemâsı ve devlet adamları da şahsî tercihleri çerçevesinde belirledikleri dinî/din dışı konulara diledikleri çeşitlilikte ve oranda yer verdikleri mecmualar hazırlamıştır (Uzun, 2003, s. 266-267). Bu kalem erbabından biri olan ve XVII-XVIII. yüzyılda devlet hizmetinde bulunan Hazine-i Birun Kâtibi ve Şıkk-1 Sani Defterdarı Göynüklü Ahmed Efendi, ${ }^{2}$ ömrünün son günlerine kadar bahis konumuz olan “Mecmua"yı yazmıştır.

Bir maliye bürokratı olan Ahmed Efendi'nin doğum tarihi hakkında kaynaklarda bilgi yoktur. Ölüm tarihi ise Sicill-i Osmânî'de Şaban 1172/Mart-Nisan 1759'dur (C. I, s. 259). Keza mecmuasindaki son kayda ait 25 Receb 1172/24 Mart 1759 tarihi de bu bilgiyi doğrulamaktadır (BN, vr. 371b/475b). Bununla birlikte Sicill-i Osmanî'de (C. I, s. 259) ve Vâsıf Tarihi'nde vefat ettiğinde yüz yaşını aşmış olduğu bilgisi de (Vâsıf, 1219,

\footnotetext{
Şiir mecmuaları, risale mecmuaları, hadis mecmuaları, fetva mecmuaları, dua mecmuaları, tarih manzumelerini içeren mecmualar, fevâid mecmuaları, hutbe mecmuaları, tıpla ilgili mecmualar, gizli ilimlerden bahseden mecmualar, letaif mecmuaları, zikir ve evrâd mecmuaları, hikâye mecmuaları, münşe'ât mecmuaları, müzikle ilgili mecmualar, mektup mecmuaları, müsvedde mecmuaları, ilâm mecmuaları, söz, deyiş mecmuaları, hadis ve tefsir benzeri kaynaklardan edinilen dinî bilgilerin yer aldığı mecmualar (Gıynaş, 2011, s. 246).

2 Göynüklü Ahmed Efendi'nin hayatı ve devlet hizmeti için bkz. Yıldız, 2019, s. 843-855.
} 
s. 156) hesaba katıldığ söylenebilir (Yıldız, 2019, s. 845).

Ahmed Efendi, yüz yılı aşkın ömrünün çok büyük bir kısmını devlet hizmetinde geçirmiştir. Uzun yıllar devam eden resmî hayatı sırasında edindiği bilgi ve tecrübelerini sonraki kuşaklara aktarmayı görev saydığından olsa gerek, önemli gördüğü ve kısmen tecrübî, kısmen de çeşitli kaynaklardan derlediği yirminin üzerinde konuya ait bilgileri eserinde bir araya getirmiştir. Bu sebeple de eserini Meсmū'a olarak zikretmeyi tercih etmiştir ("...Cümlesin işbu mecmū caya cemc edip...": Mecmî́a [Berlin Nüshası/BN], yz. 1209, 367b/277b ${ }^{3}$ ). Mecmua'daki konular arasinda özellikle Ahmed Efendi'nin XVIII. yüzyılın ilk yarısından itibaren bizzat katıldığ seferlere ait tanıklıkları, ilgili dönem olaylarının az bilinen yanlarının aydınlatılması bakımından büyük önem taşımaktadır.

Çalışmamızda, Ahmed Efendi'nin mecmuasının dünyada bilinen iki nüshasının tüm yönleriyle bilim dünyasına tanıtılması amaçlanmıştır. Bu doğrultuda, öncelikle nüshaların şu anda bulundukları yerler hakkında bilgi verilmiştir. Daha sonra, ana nüsha olan Berlin Nüshası'nın (BN) dijital kopyası ile Rado Nüshası'nın $(R N)$ orijinali karşılaştırmalı olarak incelenmiş ve elde edilen bilgiler "Nüshaların Fizikî Özellikleri" ve "Nüshaların Muhtevası" başlıkları altında değerlendirilmiştir. Değerlendirme aşamasında, gerek $B N$ 'nın restorasyonu sırasında gerekse $R N$ 'nın bazı bölümlerine sonradan Şevket Rado tarafından yapılan eklemelerde yapılan hatalara da dikkat çekilerek düzeltmeler yapılmış ve eksiklikler tamamlanmaya çalışılmıştır.

\section{Mecmua'nın Nüshaları ve Muhtevası}

Ahmed Efendi'nin mecmuasının bilinen iki nüshası vardır. Bunlardan birisi, fihristinde yazılı tüm konuları ihtiva eden Almanya'daki $B N^{\prime}$ dır. İstanbul'daki diğer nüsha olan $R N$ ise BN'nın ana konularından "Tarih" bölümünün sadece 1711-1714 yıllarında Osmanl1-Rus-İsveç ilişkilerine dair olayların kaydedildiği hacmen çok daha küçük bir parçasından ibarettir.

\section{1. Berlin Nüshası $(B N)$}

BN'nın varlığı ve nerede bulunduğu hakkında ilk bilgilere Babinger'in eserinde rastlıyoruz (Babinger, 2000, s. 341). Daha sonra nüshayı bizzat gördüğü anlaşılan Kurat, 1940 ve 1951-1953 yıllarında yazdığı kitaplarında yazma hakkında bilgi vermiş, hatta bazı bölümlerini Arap ve Lâtin harfleriyle yayımlamıştır (1943, s. V-VI, 1-31; 1951, 1953: 15-17, 741-748). Keza Kurat 1966 yılında yayımlanan makalesinde, BN ve Ahmed Efendi hakkında bilgi verdikten sonra Mecmua'nın Prut Seferi ile ilgili bölümünü ${ }^{4}$ Arap ve Latin harfleriyle yayımlamıştır (1966, s. 261-426). 1968'de ise Barbara Flemming, Almanya'da bulunan Türkçe elyazmalarını derlediği kataloğunda, çeşitli konulara ait bilgilerin yazılı olduğu bu mecmuayı incelemiş ve bilgi vermiştir. ${ }^{5}$ Son olarak Songül Çolak, BN'nı doktora tezi olarak çalışmış; gerek 1999 yılında yayımlanan tezinde ve gerekse 2004'de yayımlanan makalesinde, konu hakkında daha önce

\footnotetext{
Eğik çizgiden sonraki numaralar, nüshanın yerleri düzeltilmiş ve sonradan rakamlandırılmış varak numaralarıdır. vr. 300b/215b-326a/241a.

1968: 28/nr. 41, 151-154/nr. 191-193, 186-187/nr. 227, 203/nr. 246, 247, 256-257/ nr. 321, 323, 259-260/nr. 326, 271-272/nr. 341-342, 275-276/nr. 348-350, 319/nr. 416, 334-335/nr. 428, 338/nr. 433, 346-347/nr. 446.
} 
yapılmış çalışmalardan da yararlanarak detaylı bir araştırma yapmıştır (1999; 2004, s. 853-865). ${ }^{6}$

$B N$, günümüzde Berlin (Tübingen) Devlet Kütüphanesi kataloğunda "Staatsbibliothek zu Berlin-Preußischer Kulturbesitz, Verzeichnisses der Orientalischen Handschriften in Deutschland (VOHD) 13, 1, 446, Ms. or. quart. 1209" künyesi ve "Mecmū'a" adı ile kayıtlıdır (SSB website).

\subsubsection{Nüshanın Fizikî Özellikleri}

$B N$ 'nın cildi, muhtemelen mukavva üzerine kahverengi deri kaplıdır. Türk cilt sanatının klâsik bir örneği olan cilt kapağı, sertapl1 ${ }^{7}$ (sertâb) ve mikleplidir (mıkleb). ${ }^{8}$ Üst ve alt kapaklarının ortasında 90 × 70 mm ebadında Rûmî motifli salbeksiz ${ }^{9}$ beyzî soğuk şemse ${ }^{10}$; sertap ve mıklepin ortasında ise $30 \times 30 \mathrm{~mm}$ ebadında dilimli soğuk şemse vardır. Ayrıca sırt kısmının alt tarafında, yazmanın kütüphanede bulunduğu bölüm ve sıra numarasının olduğu sarı yaldız baskılı “Ms. Or. Quart. 1209" yazısı bulunmaktadır. Cilt ara kapakları ile mıklep iç kapağı, Hatayî formunda sarı, pembe, kırmızı, yeşil renklerle boyanmış çiçek ve yaprak motifleriyle süslenmiştir.

Yazmanın, zaman içinde restorasyon gördüğ̈̈ bellidir (Flemming, 1968, s. 346). Özellikle klâsik Türk cilt formuna göre düz olması gereken (Özen, 1985, s. 11) sırt kısmının bombeli olmasından hareketle, en azından bu kısım restorasyondan geçmiş ve şirâzesi yenilenmiştir. Nitekim ileride de görüleceği üzere birçok sayfanın fihristteki sayfa sırasına uygun olmayan yerlerde bulunması, zaman içinde şirâzenin kopmasıyla dağılan sayfaların sırasının restorasyonda yeniden ciltlenirken karıştırıldı̆̆ını göstermektedir. Keza üst kapaktan sonra orijinal varakların rengine çok yakın sarımtırak renkli ilk boş yaprak (1a'dan önce) ile alt kapaktan önceki son boş yaprak, restorasyon sırasında eklenmiş farklı ve yeni sayfalardır. Bu yapraklardan üst kapaktan sonraki sayfanın arka yüzüne, yaklaşık olarak 65 x 46 mm ebadında bir kâğıt yapıştırılmıştır. Kâğıdın üzerinde, el yazısıyla ve siyah mürekkeple "Or. qu. 1209 acc. ms. 1911.209." yazılıdır. Alt kapaktan önceki yaprağın ön sayfasında ise kurşun/sabit kalemle yazmanin toplam varak sayısı olan "372 Blatt" (372 sayfa) ve boş (unbeschrieben) varak numaralarının yazıldığı "Koll, 31.8.1977" tarihli bir kayıt vardır.

6 Bununla birlikte Göynüklü Ahmed Efendi'nin Mecmua'sının dünyada bilinen iki nüshasından BN üzerine bir doktora tezi hazırlayan Çolak'ın makalesindeki ifadelerinden ("Şevket Rado'nun bu konu ile alakalı yazdığ makalesinden anlaşıldığına göre kendi kütüphanesindedir", "Rado'nun belirttiğine göre her varaka", "Rado'nun belirttiğine göre kopya nüshadaki son varaka" "Berlin'de bulunan ve eksiksiz tek nüsha olarak nitelendirebileceğgimiz eser": 2004, s. 854-855) diğer nüsha olan $R N$ 'nı görmediği anlaşılmaktadır. Ben hemen hemen aynı yıllarda, doktora tezimin ana kaynaklarından biri olması nedeniyle öncelikle Alman Arkeoloji Enstitüsü'nün aracilığı sayesinde BN'nın negatif bir film kopyasını Staatsbibliothek'ten getirtmiştim. Daha sonra da merhum Rado'nun ailesi ile irtibat kurabilmek için telefon rehberinden çeşitli aramalar yapmış ve oğlu Mehmet Rado'ya ulaşmıştım. Kendisinden, rahmetlinin kütüphanesinde bulunan bu nüshanın fotokopisini temin edebilmek için yardımını rica ettim. M. Rado, bir kaç gün sonra yazma nüshanın bir kopyasını almama izin verdi. Böylece tezimi yazarken her iki nüshadan da faydalandım.

Klâsik ciltlerde mıkleple alt kapak arasında sayfa kenarlarını koruyan parça (Özen, 1985, s. 62).

8 Eski ciltlerde alt kapağa sertap ile bağlanıp üst kapak ile kitap arasına girerek sayfa kenarlarını koruyan ucu sivri parça (Özen, 1985, s. 46).

Eski ciltlerde şemsenin iki ucundaki uzantı süslemeye verilen isim (Özen, 1985, s. 60).

10 Eski kitap ciltlerinin üzerine yapılan güneş şeklinde süsleme motifi (Özen, 1985, s. 66) 
372 varaklı yazmanın ciltli ebadı, 320 × $230 \mathrm{~mm}$; muhtelif ölçülerdeki sayfaların ebadı ise 296-302 x 191-206 mm'dir. ${ }^{11}$ Sayfalarda kullanılan kâğıtlar; fildişi, sarımtırak, yer yer açık kahverengimsi renkte ve âharlıdır. Bazı sayfalar filigranlıdır (Flemming, 1968, s. 346). Varakların bir kısm1, cetvellidir (cedvel). ${ }^{12}$

Nüshada 53 sayfa boştur. ${ }^{13}$ Bazı varaklarda yazıların okunmasını engellemeyecek ölçüde, birkaç sayfada ise okumayı güçleştirecek derecede mürekkep dağılmaları vardır. ${ }^{14}$

Yazı türü ekseriyetle nesih, kısmen de divanî, divanî kırması, talik, rık'a ve siyakattır. Yazıların çok büyük bir bölümünde siyah mürekkep kullanılmıştır. Dikkat çekilmek istenen kelimeler, tarihler, serlevhalar, bazı çizgiler, cetvel çizgileri ile sayfa numaralarında ise kırmızı ve yeşil mürekkep tercih edilmiştir. Kırmızı ve yeşil mürekkepli çizgiler/satırlar, açıktan koyuya değişik tonlardadır.

Nüshada restorasyondan önce ve sonra olmak üzere, bir araya getirme ve ciltleme aşamasında varak sıraları büyük ölçüde karışmıştır. Nitekim Göynüklü Ahmed Efendi'den sonraki yıllarda başka biri tarafından yazılmış bir notta, müellifin birçok kaynaktan bu kıymetli bilgileri derlemesine rağmen zaman içinde varakların fihristteki sıraya aykırı olarak dağılıp karıştığı ve bunların aslına göre yeniden düzenlemesi gerektiği yazılıdır. ${ }^{15}$ Sonradan farkedilen bu durumu düzeltebilmek için müellif veya eser sahipleri tarafından yazılan Arabî varak numaralarının yanına, kurşun/sabit kalemle ve günümüz rakamlarıyla sonradan yeni bir numaralandırma yapılmıştır. ${ }^{16}$ Ancak restorasyon sırasında varaklar yanlış yerlere koyulup ciltlendiği için doğru olan yeni numaralandırmanın sırası da bozulmuştur. Keza Mecmua'da yer verilen konular ve genellikle konularla ilgili olarak belli ölçülerde ve renklerde olan cetvelli varakların sırası da karışmıştır.

\subsubsection{BN'nın Muhtevası}

Ahmed Efendi, seçtiği çeşitli konuları topladığı Mecmua'daki bilgilere zaman zaman kendi görüşlerini de eklemiştir. Ancak kendi görüşlerini belirttiği bu notların bir kısmı, nüshada farklı konuların bulunduğu varaklara yazılmıştır. Bunun iki sebebi olmalıdır. Birisi, Ahmed Efendi'nin eserini yazarken büyük ihtimalle sonradan hatırladığı ya da önemli gördüğü bazı bilgileri başka konuların bulunduğu boş

11 Mecmua hakkında bilgi veren çalışmalar, yazmanın ebadını ciltli, ciltsiz ayırımı yapmadan genel bir ölçüyle müttefikan 300 x 200 mm olarak verir (Flemming, 1968, s. 347; Çolak, 1999, s. 9; 2004, s. 854-855; Kurat, 1966, s. 264).

12 Cetvel/cedvel: Yazma eserlerin sayfalarında metni içine alan siyah ya da farklı renklerde, bir ya da birkaç çizgi ile yapılmış çerçeve (Özen, 1985, s. 9). Flemming, Kurat ve Çolak'ın çalışmalarında, cetvelli varakların çerçeve ebatları hakkında bilgi yoktur. Farklı ölçülerde olan cetvel ebatları, ileride konularına ait bölümlerde verilecektir.

13 Boş olan varaklar: 7a-9a, 29b, 55b, 75b/65b, 79b/69b-80b/70b, 81b/71b, 82b/72b-83b/73b, 88a-b/78a-b, 98a/88a, 99a/93a, 100b-101b/94b-95b, 116a-118a/203a-205a, 128b/109b, 138a-b/120a-b, 139b/121b, 140a/122a, 148b/264b, 149a-b/199a-b, 179b180a/218b-104a, 195b/277b, 198b-199a/282b-283a, 214b-215a/199b-300a, 235b/326b, 242b-243a/333b-334a, 257b-258a/348b349a, 261b-262a/352b-353a, 269b/359b, 304b/364b, 372a-b/476a-b.

14 vr. 143a-b/255a-b, 148a-b/264a-b, 173a-b/233a-b, 175a-176b/235a-231b, 181a-182b/234a-230b, 184a-b/237a-b, 190a-b/314ab, 194a-195b/271a-277b, 371a-b/474a-b.

15 vr. 190b/214b. Bu sayfanın sağ sütununda bulunan kaydın hattı, yer yer nesih izleri görülen rık'adır. 274 x 155 mm ebadında siyah renkli çift çizgi cetvelli ve ortası yeşil çift sütunlu cetvellidir.

16 vr. 69a'ya kadar aynı olan Arabî ve yeni numaralandırma, 70a'dan itibaren değişmektedir. Bu varakta Arabî rakam 70 olması gerekirken 65 olarak yazılmıştır. 
varaklara kaydetmesidir. Diğeri ise nüshanın restorasyonu sırasında kopan/dağılan varakların, hatalı numaralandırma yüzünden yanlış sırayla ciltlenmesidir.

$B N ' n ı$ inceleyen Flemming, bu karmaşıklığı düzeltebilmek için nüshada yer verilen konuları 20 ana bölümde toplamış ve varakları, yazmadaki sırasına bakmaksızın ilgili oldukları konunun bulunduğu bölümlerde göstermiştir. ${ }^{17} \mathrm{Bu}$ çalışmada ise Flemming'in Mecmua'daki bilgileri belli konular altında toplama yöntemi benimsenmekle birlikte; bazı konular varak numaraları ile birlikte ilgili oldukları diğer konuların bulunduğu bölüme dahil edilmiş; bazı konular da birleştirilmiş oldukları konu grubundan çıkarılarak müstakil yeni bir konu başlığı altında gösterilmiştir. Bu suretle Mecmua'da zahriyye, serlevha-elkâb, fihrist-özetler ve kronoloji dışında alt başlıklar halinde yirminin üzerinde konu tespit edilmiştir. $B N$ 'nın tüm bölümleri ise şu şekilde tasnif edilmiştir:

Zahriyye (1a):18 Tezhipsiz olan zahriyyenin en üstünde, sağ tarafında ve alt kısmında, özensiz ince talik hatla bazı hastalıklar için bitkisel ilaç tarifleri ve tılsımlar yazılıdır. ${ }^{19}$ Sol tarafta ise iki "temellük/tesâhüb kaydı"na ${ }^{20}$ ait iki mühür bulunmaktadır. Sağdaki mühür, sahiplik kaydı kırmızı mürekkeple yazılmış "Mehemmed Reşîd"e aittir. Mührün altındaki غقصد ibaresi, ebced hesabı ile hicrî "1194" (1780) tarihini vermektedir. Soldaki diğer mühür, sahiplik kaydı siyah mürekkeple yazılmış olan "Ahmed Şerîf"e aittir. Bu kayıtta tarih yoktur. Ancak "Serhalîfe-i kalem-i kale-i kebîr" unvanlı bu zatın Osmanlı maliye kalemlerinden birinin şefi olmasından hareketle, maliyenin en kıdemli yöneticilerinden/kâtiplerinden Ahmed Efendi'yi ve mecmuasını tanıyor olması çok muhtemeldir. Dolayısıyla temellük kaydında tarih bulunmamasına rağmen, müellifle aynı teşkilat bünyesinde görev yapan Ahmed Şerîf'in yazmanın ilk sahibi olması ihtimali daha yüksektir. Sayfanın alt kısmında ise yazmaya ait üçüncü temellük kaydını gösteren bir kütüphane mührü vardır. Kırmızı mürekkeple bir daire içinde "Ex Biblioth. Regia Berolinensi" yazılı olan bu tarihsiz mühür, ${ }^{21}$ yazmanın daha sonraki yıllarda satın alma ya da başka bir yolla Osmanlı İmparatorluğu sınırları dışına çıkarıldığını ve Berlin Kraliyet Kütüphanesi (Staatsbibliothek zu Berlin) mülkiyetine geçtiğini göstermektedir.

Serlevha/Mihrâbiyye22 ve Elkâb (vr. 1b-2b): 1b'de, dördü açık kırmızı ve biri yeşil beş çizgili yarım daire şeklinde tezhipsiz çok basit bir serlevha/mihrâbiyye vardır.

17 Flemming, 1968, s. 28 (nr. 41); 151-154 (nr. 191-193); 186-187 (nr. 227); 203 (nr. 246-247); 256-257 (nr. 321-323); 259-260 (nr. 326); 271-272 (nr. 341-342); 275-276 (nr. 348-350); 319 (nr. 416); 334-335 (nr. 428); 338 (nr. 433); 346-347 (nr. 446).

18 1a. Yazma eserlerin başlık bulunan ilk sayfasından önce, temellük kaydı bulunan çoğunlukla tezhipli bazen de boş sayfa (Özen, 1985, s. 78).

19 Vefk ve cifr kullanımı, halk arasında olduğu kadar Osmanlı devlet adamlarında da yaygındı (Tezcan, 2017, s. 173; Uluğ, 2017, s. 179). Mesela Göynüklü Ahmed Efendi'nin Mecmua'yı tamamladığ1 yıllarda, bir başka devlet adamı Kaptan-1 Derya Köse (Mirahor, Elçi) Mustafa Paşa da içinde mukataalar, sadaret tebdilleri, ilaç reçeteleri, vefkler ve tılsımların yer aldığı 1153-1179/1741-1766 tarihli bir "Defter" kaleme almıştı (Tezcan, 2011, s. 19, 191). Yine aynı dönemlerde; 1186/1772 tarihinde Osmanl1-Rus savaşına son verilmesi için Eflâk ile Boğdan sınırındaki Fokşani kasabasında Osmanl1Rus heyetleri arasındaki barış görüşmeleri sırasında Padişah III. Mustafa, Rusları barışa razı edebilmek için büyüye başvurmuştu (Topkapı Sarayı Müzesi Kütüphanesi, E. 3809/2-655/19; Öz, 1942, s. 101-103).

20 Yazma eserin ait olduğu kişiyi/kişileri ya da kitaplığı bildiren kayıt. Genellikle zahriyye sayfasında bulunur (Özen, 1985, s. 70).

21 Aynı mühür, yazılı son varak olan 474b/371b'nin en altına da basılmıştır.

22 Yazma eserin çeşitli süsleme şekilleriyle tezhiplenen (bazen ucunda tı̆̆ çizgileri olan) ya da sadece yazı olan baş sayfası (Özen, 1985, s. 46, 62). 
Serlevhanın altında sirasiyla besmele, hamdele-salvele, ${ }^{23}$ dibâce/mukaddime ve duâ cümleleri ${ }^{24}$ vardır. Bunun ardından çeşitli devlet memuriyetlerine ait elkâbın fihristi bulunmaktadır $(2 \mathrm{a}-2 \mathrm{~b}) \cdot{ }^{25}$

Fihrist ve Özetler (vr. 2b-6b): Anadolu ve Rumeli'deki eyaletler, kazalar ve buralardan alınan çeşitli vergilerle ilgili fihrist yer alır (2a-4b). Ardından, Mecmua'da bulunan çeşitli konulara ait özetler (matlab) ve varak fihristi vardır (5a-6b). Siyah mürekkepli hattın büyük kısmı nesih, bir kısmı ise divanîdir. Fihrist numaraları, başlıklar ve dikkat çekilmek istenen kelimeler açık kırmızı mürekkepli; madde başlarının ise bir bölümü açık kırmızı, bir bölümü de yeşil mürekkeplidir. ${ }^{26}$

Kronoloji (vr. 167a/126a-170b/138b):27 Osmanl1 tarihinde 1562-1563 ile 1619-1620 yılları arasında savaş, sefere gidiş-dönüş, fetih, zafer, yenilgi, ölüm, istilâ, İsyan, azil, cülus, tashih-i sikke vb. önemli olaylar, sıra numaralı kronolojik olarak her sayfada onar senelik tablolar ${ }^{28}$ hâlinde gösterilmiştir. Bunun yanı sıra, 1522-1523 ile 1564-1565 yılları arasındaki bazı tarihlere ait önemli görülen olaylar, 167a/126a varağına derkenar olarak eklenmiştir. Ayrıca Göynüklü Ahmed Efendi'den sonra kitap sahiplerinden biri ya da başka birisi bu tarih kronolojisi çalışmasını devam ettirmek istemiş ve 170ab/138a-b varaklarına çizdiği tablolara, 1776-1777 ve 1785-1786 başlıkları altında, fakat onar yıllık sıraya uymadan tarihsiz ya da geç tarihli bazı kayıtlar düşmüştür. ${ }^{29}$ Hat, 167a/126a-169b/128b varaklarında Türkçe nesih; 170a-b/138a-b varaklarında ise ekseriyeti rık'a olmak üzere kısmen nesih, kısmen divanî hatlı Farsça'dır. Bazı sayfalarda derkenarlar vardır. Başlıklar, dikkat çekilmek istenen kelimeler, bazı kelimelerin üstüne çizilen çizgiler, tarihler, bazı sıra numaraları ve vakfeler, ekseriyetle kahverengiye dönük kırmızı, kısmen de açık kırmızı mürekkeplidir. Arabî varak numaraları ise pembeye dönük kırmızı renklidir. ${ }^{30}$

Elkap, Mektup, Tezkire, Arz-ı hâl, Öğütler, Notlar:31 Devlet kadrolarında çeşitli memuriyetlerde görev yapan amir ve memurlar ile Mekke-Medine gibi kutsal beldelerin yöneticileri, Kırım hanları, bazı hükümdarlara yazılacak mektuplar ve bu mektuplarda kullanılacak elkap ile çeşitli makamlara yazılan tezkire ve arz-1 hâl suretleri vardır:

23 Hamdele, "El-Hamdü lillâh"ın kısaltılmış halidir. Salvele ise "Ve's-salâtü ve's-selâmu calâ Seyyidinâ Muhammedin ve calâ âlihî ve sahbihî ecmacîn"in kısaltılmış haline verilen addır.

24 "Bismillâhirrahmânirrahîm. El-hamdu li'llâhi Rabbi'l-âlemîn. Ve's-salâtu 'alâ Resûlinâ Muhammed ve 'alâ âlihi ve sahbihi ecma î̀n. Ammā ba'd mâ yeştemilu 'alâ hikâyâti's-sâlihîn ve letâyifü'l-kibâr ve zikrü'l-ashâb Rıdvânallahu te âlâ 'aleyhim ecma î̀n. Bu hakîr-i pür-kusûr, ba'zı kitâblardan ahz olunup ba zı mübtedîler anlayıp; ve bu hakîr dahi bir Fâtiha-i şerîf ile rûhuna hîbe edeni, Tanrı te âlâ murâdât-ı maksûdâtın ve müşkilâtın hall edip, tûl ömr ile mu 'ammer ve mu 'azzez ü mükerrem ede Cenâb-ı Bârî! Âmin, bi-hürmeti Seyyidi'l-mürselîn".

25 Varaklar, 265-270 x 144-147 mm ebadında beş açık kırmızı arasında bir yeşil çizgi cetvellidir.

26 Varaklar, 265-278 x 144-151 mm ebadında, üç açık kırmızı arasında bir yeşil çizgili cetvellidir.

27 Sırası karışmış olan bu varaklar, 166b/316b varağının arkasına girdiği için restorasyon sonrasındaki sıraya göre yeni numaralandırmada 167 olarak rakamlandırılmıştır.

28 Tablolandırılmış yıllar: 970/1562-1563, 980/1572-1573, 990/1582-1583, 1000/1591-1592, 1010/1601-1602 ve 1020/1611-1612.

Düşülen son kayıt, 1252/1836-1837 tarihlidir.

Varaklar, 283-285 x 153-155 mm ebadında siyah çift çizgi cetvellidir.

vr. 11b-14a/11-14, 54b-55a/54-55, 81b/71b, 171a/208a, 172a-175b/101a-235b, 177b/103b (Bu varağın sirası, muhtemelen restorasyon sırasında karışarak 171b/208b'nin arkasına girmiştir), 180b/104b-181b/234b, 183a/105a/145a (Biri kırmızı mürekkeple 145, diğeri siyah mürekkeple 105 olarak iki Arabî numara verilen bu varakta, sonradan divanî hatla ters olarak yazılmış 5 Zilkade 1254/20 Ocak 1839 tarihli maliye tezkiresi suretleri vardır), 184a-b/237a-b, 150a/140a155b/181b. Ayrıca tüm varakların yer ve rakam sıralarında karışıklıklar vardır. 
11b-14a: Tatar hanı, Mekke-i mükerreme şerîfi, Leh kralı vb. ile devlet kadrosunda çalışan çeşitli âmir ve memurlara hitaben yazılan resmî belgelerde kullanılan elkap cümleleri kaydedilmiştir. Hat, divanîdir. Ara başlıkların, griye dönük yeşil mürekkepli olan biri hariç tümü ve varak numaraları, kahverengiye dönük kırmızı mürekkeplidir. ${ }^{32} 21$ ve 23 satırlı olan varaklar (14b: 6 satır) "ayaklı"33 ve cetvelsizdir.

54b: Darüssaade ağaları tarafından yazılan imzalı ve dikey olarak yazılmış iki arz/arz-1 hâl örneği vardır. Hat, divanîdir. Başlık ve dikkat çekilmek istenen kelime, açık kırmızı mürekkeplidir. ${ }^{34}$

55a: Çakırcıbaşı tarafından Eskişehir kadısına yazılan kuyruklu imzalı bir mektup sureti vardır. Hat, divanîdir. Başlık, koyu pembe renklidir. ${ }^{35}$

81b/71b: Maliye teşkilâtında taşra hazinesinde (hazine-i birun) görev yapan hazinedarbaşının nasıl mübayaa tezkiresi yazacağına dair çeşitli tezkire sureti örnekleri bulunmaktadır. Hat, kısmen nesih, kısmen divanî ve kısmen siyakattır. Başlık ve dikkat çekilmek istenen kelime açık kırmızı, varak numarası koyu pembeye dönük kırmızı mürekkeplidir. ${ }^{36}$

172a-175b/101a-235b, 177b/103b, 180b/104b-181b/234b, 183a/105a/145a, 184a-b/237ab: Alt makamdan üst makama, üst makamdan alt makama ve orta makamdan orta makamlara yazılan rica tezkiresi, iftar tezkiresi vb. tezkire müsveddeleri, mektuplar ile padişaha, sadrazama, vakıflara yazılacak arz-1 hâl örnekleri bulunmaktadır. Hat, nesih ve divanîdir. 172a/101a, 174b/102b ve $177 \mathrm{a} / 103 \mathrm{a}$ ve $184 \mathrm{~b} / 237 \mathrm{~b}$ 'de derkenarlar vardır. 173a/233a'da, sütun başlarında üç açık kırmızı bir yeşil çizgili iki yarım daire şeklinde çok basit serlevhalar vardır. 173a/233a ve 175a/235a varakları matlaplıdır. Başlıklar, memuriyet unvanları ve dikkat çekilmek istenen kelimeler, kelimelerin üstüne çizilen çizgiler ve vakfeler; koyu pembeye dönük kırmızı, pembeye dönük kırmızı ve açık kırmızı mürekkeplidir. 173a/233a'daki başlıkların bazı kelimeleri ile serlevha kenarındaki bazı süsler ve orta sütun çizgileri yeşil mürekkeplidir. ${ }^{37}$

180b/104b-181b/234b, 183a/105a/145a: Göynüklü Ahmed Efendi'nin boş biraktığ1 ve sonraki tarihlerde yazma sahiplerinden biri ya da bir başkası tarafından rık'a hatla üst makamlara yazılmış arz-ı hâl suretleri ve divanî hatla ters yazılmış maliye tezkiresi suretleri vardır. ${ }^{38}$ 181a/234a ve 184a-b/237a-b varakları matlaplıdır. Başlıklar ve ara çizgileri açık kırmızı mürekkeplidir. ${ }^{39}$

150a/140a-155b/181b: Yüksek mertebeli olandan yüksek mertebeliye, orta mertebeli olandan orta mertebeliye, alt mertebeliden alt mertebeliye, alt mertebeliden üst

vr. 11b'de rakam yazılmaması gerektiği halde, "। " olarak numaralandırılmıştır.

Yazma eserlerde sayfa sırasının karışmaması için sağ sayfadaki "a" varağının ilk harfinin ya da kelimesinin, sol sayfadaki " $b$ " varağının son satırının sonunda tekrar edilmesi demek olan "ayak"a; râbıta, reddâde, rakabe, çoban, murâkıb, müş'ir, müşîr, müşîre, pâyende, müşâhide, ta'kîbe ve garip de denilirdi (Özen, 1985, s. 5; Abdulkadiroğlu, 1997, s. 549).

34 Varaklar, $278 \times 148$ mm ebadında, çift siyah çizgi cetvellidir.

35 Varaklar, $274 \times 149$ mm ebadında, çift siyah çizgi cetvellidir.

36 Varaklar, $277 \times 161 \mathrm{~mm}$ ebadında, çift siyah çizgi cetvellidir.

37 Cetvel ebatları 278-285 x 148-156 mm olan varaklardan 172a-b/101a-b, 174a-b/102a-b, 177a-b/103a-b, çift siyah çizgi cetvelli (172b/101b'nin alt cetveli silinmiş); 173a-b/233a-b, 175a-b/235a-b ve 181a-182a/234a-230b varakları, siyah çift çizgi cetvelli ve ortası yeşil çift sütunludur.

38 Varaklar, 275-283 x 149-156 mm ebadında siyah renkli çift çizgi cetvellidir.

39 Varaklar, 278, $280 \times 150$, 152 mm ebadında siyah renkli çift çizgi cetvelli ve ortası yeşil çift sütunludur. 
mertebeliye yazılacak "muhabbet" cümlelerinin nasıl olması gerektiğine dair ögütler, notlar, mektup örnekleri vb. bulunmaktadır. Hat, nesihtir. Varakların satır sayıları muhteliftir. ${ }^{40} 150 \mathrm{a} / 140 \mathrm{a}$ 'da üçü açık kırmızı, biri yeşil dört çizgili yarım daire şeklinde çok basit bir serlevhası vardır. Serlevha ile cetvel arası, yine açık kırmızı ve yeşil mürekkepli "م" harfleri ile süslenmiştir. Başlıklar, dikkat çekilmek istenen kelimeler, bazı kelimelerin üzerine çizilen çizgiler, vakfeler, ekseriyetle açık kırmızı mürekkepli ve nadiren yeşil mürekkeplidir. ${ }^{41}$ Değişik renklerde ve ölçülerde cetvelli ${ }^{42}$ olan varakların bazıları derkenarlıdır. ${ }^{43}$

Ahvâl-i Malta (vr. 128a/109a): Macaristan'ın bağımsızlığı için Avusturya ile mücadele eden ve Tekirdağ'da ikâmet etmekte olan eski Erdel Prensi I. Ferenc Rakoczi'nin (Rakoçi) oğlu Josef Rakoczi'ye (Rakopsaoğlu) gönderilen bir mektup suretidir. Ahvâl-i Malta başlığı altında yazılan mektupta; 1726-1727 senesinde bir gün Malta'da başlayan kasırga sırasında, binden fazla yıldırım düşmesi sonucunda binlerce insanın ve hayvanın hayatını kaybetmesi ve gemilerin batmasına dair olaylar anlatılmaktadır. Hat, tek sütuna yazılmış nesihtir. Başlık, dikkat çekilmek istenen kelime, Arabî varak numarası ve vakfeler, pembeye dönük kırmızı mürekkeplidir. ${ }^{44}$

Arazi Kanunlarl, Timar Sistemi, Vakfiyet, Kale Gedikleri: ${ }^{55}$ Çeşitli tarihlerde timar sistemi ile çeşitli raiyyet ve arazi vergilerine dair çıkarılan kanun suretleri, arazi hukuku, vakfiyet, kale gedikleri, alım-satım vb. konularla ilgili hükümler yer almaktadır:

14b-52b: Kanuna göre çeşitli raiyyet ve arazi vergileriyle ilgili şikâyetlere yazılan hüküm örneklerinin bulunduğu bölümdür. Hat, divanîdir. Başlık, ara başlıklar ve dikkat çekilmek istenen kelimeler, kahverengimsi kırmızı mürekkeplidir. 21-23 satırlı (29a, 30a, 38a hariç) olan varaklar, ayaklı ve cetvelsizdir.

53a: 1609 yılında Ayn Ali Efendi'nin hazırladığı "yeni kanun"dan"6 (Risâle-i Vazîfehôrân ve Merâtib-i Bendegân-1 Âl-i Osmân) naklen, timar/zeâmet topraklarının tasarrufu hakkında Trabzon beylerbeyine ve eyalette bulunan kadılara hitaben yazılmış bir hüküm sureti vardır. Cetvelsiz olan varaklar, nesih hatlı ve 34 satırlıdır. Başlık, tarihler, dikkat çekilmek için bazı kelimeler altına çekilen kısa çizgiler, kahverengimsi kırmızı mürekkeplidir.

53b-54a: 1375 yılında I. Murad'ın, Niş şehrini fethettiken sonra Rumeli Beylerbeyi Timurtaş Paşa'nın tavsiyesi ile Niş topraklarında timar sisteminin kurulması ve timar topraklarının hak sahiplerine dağıtılmasına dair çıkardığı kanun metninin sureti

40 Varaklar 34-36, 38-39 ve 44 satırlıdir.

41 vr. 151a/189a, 152a/185a/155b, 153a/186b, 154a/182b ve 155a/181a (Arabî sıra numaraları karışmış) matlaplıdır.

42 150a-b/140a-b varağı, 270-274 x 145-147 mm ebadında açık kırmızı renkli çift çizgi cetvelli (150a/140a üç çizgi cetvelli) ve ortası yeşil çift sütunludur. 151a/189a-155b/181b varakları ise 270-274 x 145-153 mm ebadında sağ-sol yeşil renkli, üst-alt açık kırmızı renkli çift çizgi cetvellidir.

43 vr. 152a-b/185a-b, 153b/186b.

44 Varaklar, 275 x 153 mm ebadında koyu pembeye dönük kırmızı renkli çift çizgi cetvelli ve çift sütunlu cetvellidir.

45 vr. 14b-54a/14-54, 83b/73b-87b/77b, 129a/110a-131b/112b, 127a-b/113a-b (Muhtemelen restorasyon sirasinda yeri karışarak risalenin başlangıç varağından daha önceki varaklar arasına giren bu varak, yukarıda olması gereken sıraya alınmıştır), 132a/114a-136b/118b.

6 Ayn Ali Efendi'nin hazırladığı kanunnameler için bkz. İpşirli, 1991, s. 259. 
bulunmaktadır. Başlık, dikkat çekilmek istenen kelimeler ve rakamlar, açık kırmızı mürekkeplidir. Hat, nesihtir. ${ }^{47}$

76a/66a-79a-b/69a-b: Timar sistemi ve reâyâ vergileri, arazi hukuku, kale gedikleri, ulufenin kesilmesi, vakfetme, şahsî alım-satım vs. ilgili temessük suretleri vardır. Hat, divanîdir (nesihle yazılmış vakıfla ilgili bir temessük sureti hariç). Konu başlıkları, dikkat çekilmek istenen kelimeler, vakfeler ve varak numaraları, açık kırmızı ve koyu pembeye dönük kırmızı mürekkeplidir. İlk varak olan 76a/66a'da, yarım daire şeklinde üç açık kırmızı renkli yarım daire çizgili çok basit bir serlevha yer alır. Varaklar, değişik ölçü ve renklerde cetvellidir. ${ }^{48}$

83b/73b-87b/77b: Müezzinzâde Ali (Ayn Ali) Efendi'nin 1607 yılında Veziriazam Kuyucu Murad Paşa'ya sunduğu Kavânîn-i Âl-i Osmân der-Hulâsa-i Mezâmîn-i Defter-i Dîvân adlı meşhur kanunnamesinin timar, zeamet sistemi ve uygulamalarına ait bölümleri yazılıdır. Ahmed Efendi, bölümün başlığında kanunnameyi bizzat kendisinin kopya ettiğini belirtir. Hat, ekseriyetle divanî ve yer yer siyakat; 83b/73b'nin tümü ile 87a/77a'nın kısa bir bölümü ise nesihtir. ${ }^{49}$ Başlıklar, dikkat çekilmek istenen kelimeler/cümleler, eyalet/sancak isimleri üzerindeki kısa çizgiler, rakamlar, Arabî varak numaraları ve vakfeler, koyu pembeye dönük kırmızı mürekkeplidir. ${ }^{50}$ Varaklar, değişik ebatlarda ve renklerde cetvellidir. ${ }^{51}$

129a/110a-131b/112b, 127a-b/113a-b, 132a/114a-136b/118b: XVII. yüzyıl devlet adamlarından Aziz Efendi'nin, devletin idarî-askerî sistemindeki bozukluklar ile bunlara ait çözümleri kaleme aldığı ve 1632 yılında tamamladığı Kânûnnâme-i Sultânî li-Azîz Efendi adlı risalesinin istinsah edilmiş bir kopyası vardır. ${ }^{52}$ Hat nesih ve her varakta 29 satırlıdır. Başlıklar, dikkat çekilmek istenen kelimeler, tenvinler, vakfeler ve Arabî varak numaraları pembeye dönük kırmızıdır..$^{53}$

Harçlar ve Avâid:54 Tersâne-i âmire'de görev yapanların maaşları, harçları, tayinleri gibi konular ile zaîm, gedikli çavuşlar, müteferrikalar, kâtipler, şâkirdler ve maliye kalemlerinin şef, amir gibi idarecilerinin yaptıkları resmî hizmetlerden elde ettikleri çeşitli gelirlerin (avâid) dökümüne ait açıklamalar bulunmaktadır. Hat, divanîdir. Başlıklar, dikkat çekilmek istenen kelimeler ve vakfeler, lal mürekkeplidir. ${ }^{55}$

\section{Hilye-i Şerif, El-Mevâhibü'l Ledüniyye ve Incil'de Hz. Muhammed'in Özellikleri:56}

89a/79a: Bir hilye-i şerîf ile Ahmed Efendi'nin bu hilye-i şerîfi görüp kaydedenlerden kendi ruhu için Fatiha isteğine dair duası bulunmaktadır. Hat, ekseriyeti harekeli nesihtir. Başlık, Hz. Muhammed'in fiziksel özelliklerinin yazıldığ

Varaklar, 268, $278 \times 148,150$ mm ebadında çift siyah çizgi cetvellidir.

76a-b/66a-b, 78a/68a-79a/69a varakları, 277-282 x 147-153 mm ebadinda çift siyah çizgi cetvelli; 77a-b/67a-b, 80a-b/70a-b varakları ise 282, $284 \times 149,152$ mm ebadında, açık kırmızı çift çizgi cetvelli ve ortası yeşil çift sütunludur.

$83 \mathrm{~b} / 73 \mathrm{~b}-85 \mathrm{~b} / 75 \mathrm{~b}$ varakları, yaklaşık 40 derecelik bir eğimle yazılmıştır.

vr. 85b/75b'deki iki satırın tamamı ile iki satırın bazı kelimelerinde, sarımtırak açık yeşil renkli mürekkep kullanılmıştır.

83b/73b varağı, 270 x 155 mm ebadında açık kırmızı renkli, ortası yeşil çift çizgi cetvelli ve çift sütunlu; 84a/74a-85b/75b varakları, 278, 280 x 148, 150 mm ebadında siyah çift çizgi cetvelli ve çift sütunlu; 86a/76a-87b/77b varakları, 278-282 x 153 mm ebadında koyu pembeye dönük kırmızı çift çizgi cetvelli ve çift sütunludur.

52 Aziz Efendi'nin kanunnamesi için bkz. Flemming, 1968, s. 186-187; Murphey, 1985; Çolak, 1985, s. 101-112.

53 Varaklar, 280-285 x 149-155 mm ebadında lal rengi çift çizgi cetvelli ve çift sütunludur.

vr. 10b-11a.

vr. 10b, 287 x 156 mm ebadında iki açık kırmızı çizgi cetvellidir. 11a ise cetvelsizdir.

vr. $89 a / 79 a, 103 a / 114 a$ 
kelimeler, bazı kelimelerin altına konulan kısa çizgiler, vakfeler, Arabî varak numarası ve içine hilyenin yazıldığ $162 \mathrm{~mm}$ çapındaki dört çizgili daire, kırmızı mürekkeplidir. ${ }^{57}$

103a/114a: Varağın sağ tarafında, dış çapı 98 mm olan iç içe üç daire içinde Ahmed b. Muhammed el-Kastallânî'nin ${ }^{58} \mathrm{~Hz}$. Muhammed'in hayatı ve şahsiyetine dair siyer kitabı El-Mevâhibü'l Ledüniyye adlı eserinden ${ }^{59}$ alınmış kısmen Türkçe, kısmen Arapça bazı cümleler yazılıdır. ${ }^{60}$ Varağın alt kısımda, İncil'de Hz. Muhammed'in özelliklerine dair kelimelerin bulunduğu on üç küçük daire ${ }^{61}$ vardır. Hat, ekseriyeti harekeli nesihtir. Sayılar ve vakfeler açık kırmızı renklidir. Dairelerin çizgileri ile içlerindeki yazılar ise açık kırmızı ve griye dönük yeşil mürekkeplidir. ${ }^{62}$

Hz. Muhammed'in Hadisleri ve Hadis Meâlleri (vr. 164b/210b, 171b/208b, 187b/211b190a/214a): Hz. Muhammed'in çeşitli konularla ilgili Arapça hadisleri ve bazı hadislerin şiir formlu, kafiyeli dörtlükler hâlinde Türkçe meâlleri vardır. 164b/210b'de hat, harekeli bazı kelimeler hariç harekesiz nesihtir. Dikkat çekilmek istenen kelimeler, bazı kelimelerin altına çekilen çizgiler ve vakfeler, pembeye dönük kırmızı mürekkeplidir. ${ }^{63} 171 \mathrm{~b} / 208 \mathrm{~b}$ 'da hat, nesihtir. Her iki sütunun başında da ikisi açık kırmızı, biri yeşil üç çizgili iki yarım daire şeklinde çok basit serlevhalar vardır. Ayrıca varağın sağ tarafında, bir matlap ve derkenar bulunmaktadır. Başlıklar, dikkat çekilmek istenen kelimeler, fasıllar ve vakfeler, açık kırmızı mürekkeplidir. ${ }^{64}$ 187b/211b-190a/214a'da Arapça hadisler harekeli nesih, meâlleri ise harekesiz nesih hatla yaklaşık 45 derece eğik yazılmıştır. 188a/212a, 189a/213a, 190a/214a varakları matlaplıdır. Başlıklar, hadisler, bazı kelimelerin üzerine çekilen çizgiler, virgüller, vakfeler ve Arabî varak numaraları, koyu pembeye dönük kırmızı mürekkeplidir. ${ }^{65}$

Bin Soru (vr. 56a-63b): "Bin Soru" adlı Farsça bir eserden tercüme edilen ve Abdullah b. Selâm ${ }^{66}$ tarafından Hz. Muhammed'e sorulan yaklaşık iki yüz soru ve cevap bulunmaktadır. 63b'nin sonunda, Göynüklü Ahmed Efendi'nin Fatiha talep eden duası vardır. Hat, ekseriyeti harekeli nesihtir. Başlık, dikkat çekilmek istenen kelimeler, bazı harekeler, vakfeler ve sondaki "temmet" yazısı lal mürekkeplidir. ${ }^{67}$

Hz. Ali'nin Sözleri (vr. 107b/257b, 118b/205b-120a/207a): Hz. Ali'nin hikmetli sözleri yazılıdır. Hat, her bir varakta 29 satır bulunan ekseriyeti harekeli nesihtir (107b/257b hariç). Başlık, dikkat çekilmek istenen ve altına çizgi çekilen kelimeler ile vakfeler, pembe ve koyu pembeye dönük kırmızı mürekkeplidir. ${ }^{68}$

\footnotetext{
Varaklar, 282 x 155 mm ebadında, lal renkli çift çizgi cetvelli ve çift sütunludur.

XV-XVI. yüzyıllarda yaşamış Mısırlı bir hadis hafızı, kelâm ve kıraat âlimi (Bkz. Şenel, 2001, s. 583-584).

Söz konusu cümlelerin yazıldığı en içteki dairenin son iki kelimesi olan "min-Mevâhib" ile El-Mevâhibü'l Ledüniyye eseri kastediliyor olmalıdır.

El-Mevâhibü'l Ledüniyye için bkz. Algül, 2004, s. 421.

61 On üç dairenin yanında, ne amaçla çizildiği belli olmayan açık kırmızı renkli ve içi yazısız bir daire daha vardır.

Varaklar, 255 x 153 mm ebadında, açık kırmızı renkli çift çizgi cetvellidir.

Varaklar, 282 x $155 \mathrm{~mm}$ ebadında çift siyah çizgi cetvelli ve ortası yeşil çift sütunlu cetvellidir.

Varaklar, $282 \times 155 \mathrm{~mm}$ ebadında siyah renkli çift çizgi cetvelli ve ortası yeşil renkli çift sütunludur.

Varaklar, 274-281 x 153-157 mm ebadında siyah renkli çift çizgi cetvelli ve ortası yeşil çift sütunludur.

66 Hz. Muhammed ile tanışıp müslüman olan bir Yahudidir. Asıl adı Husayn iken, müslüman olduktan sonra Peygamber tarafından "Abdullah" ismi (Ebû Yûsuf Abdullah b. Selâm b. e'l-Hâris) verilen ve cennetle müjdelenen bir sahabîdir. 663-664 yılında Medine'de vefat etmiştir (Fayda, 1988, s. 134).

67 Varaklar, 274-278 x 146-152 mm ebadında, lal renkli çift çizgi cetvelli ve çift sütunlu cetvellidir.

68 Varaklar, 268-275 x 142-150 mm ebadında açık kırmızı ve koyu pembeye dönük kırmızı renkli çift çizgi cetvelli ve çift sütunlu cetvellidir.
} 
Önemli Peygamberler, Dört Halife, Sahabeler, Salihler, Ashâb-ı Kehf, Bazı Din Büyükleri, Dünyaca Ünlü Âlimler ve Havâss İçin Dualar:69

91a/81a-97b/87b: Önemli peygamberler, dört halife, Ashâb-1 Kehf, ve bazı din büyükleri ile âlimlerin kısa hayat hikâyeleri, İslâm coğrafyasında en eski tarihlerden beri hüküm süren hükümdarlar, milletler, hanedanlar ve aşiretlerin ortaya çıktıkları, hüküm sürdükleri yerler ve yıllar anlatılmıştır. Bazı isimler, yerler ve yıllar, basit çizelgelerde gösterilmiştir. Hat, kısmen eğik yazılmış nesihtir. Derkenarlar, nesih ve siyakattır. Başlıklar, yuvarlak daireler içine yazılan Ashâb-1 Kehf, peygamber isimleri, dikkat çekilmesi istenen kelimeler ve tarihler, dört halifenin başlık satırları, satır aralarına konulan konu çizgileri, bazı derkenarlar, 92/82b'deki basit üç çizgili serlevha, çizelgeler, vakfeler, Arabî varak numaraları ve cetveller, koyu pembeye dönük kırmızı mürekkeplidir. ${ }^{70}$

104a-108b/248a-254b: Din büyükleri, sahabeler ve sâlihlerin hayatlarından önemli olaylar yazılıdır. Hat, ekseriyeti yaklaşık 45 derece eğik yazılmış nesihtir (104a/248a ve 105a/249a varaklarındaki matlaplar ile birlikte). Sadece son varaktaki sağ sütun, divanîdir. 105a/249a varağında derkenar vardır. Başlıklar, "fasıl"lar, dikkat çekilmek istenen kelimeler, bazı kelimelerin altına çizilen çizgiler, ara çizgileri ve vakfeler, açık kırmızı, koyu pembeye dönük kırmızı ve lal mürekkeplidir. 104a/248a'da, açık kırmızı, koyu pembeye dönük kırmızı ve yeşil renkli beş çizgili yarım daire şeklinde çok basit bir serlevhası vardır. Bu varak, üç açık kırmızı ve bir yeşil renkli dört çizgi cetvelli ve sütunsuzdur. ${ }^{71}$

143a/255a-145b/258b: Göynüklü Ahmed Efendi'nin çeşitli kaynaklardan derlediği geçmiş zamanlarda yaşamış büyük bilgeler, din ulularının hikmetli sözleri ve hayat hikâyelerindeki önemli olaylar ile riyazette olan havâss için İhlâs-1 Şerif zikri ve benzeri dualar yazılıdır. Ayrıca 143a/255a'da, Nahîfî Efendi'nin ${ }^{72}$ iki beyiti73 ile 145b/258b'de kime ait olduğu belli olmayan iki beyit ve Tâcü'l-Ârifîn Seyyid Ebu'lVefâ'ya ${ }^{74}$ yazılmış beyitler vardır. Hat, ekseriyeti harekeli nesihtir. ${ }^{75}$ Başlıklar, dikkat çekilmek istenen kelimeler, bazı kelimelerin altına çizilen çizgiler, bir derkenar, virgüller ve vakfeler, pembe ve koyu pembeye dönük kırmızı mürekkeplidir. ${ }^{76}$

192b/252b-196b/211b: Sahabeler ve salihlerin hayatına dair önemli olaylar ve hikâyeler, Hz. Ali, din büyükleri, Eflatun, Aristo, Pisagor ve diğer eski filozofların

69 vr. 91a/81a-97b/87b, 104a-108b/248a-254b, 143a/255a-145b/258b, 192b/252b-196b/211b.

70 Varaklar, 278-283, 285 x 147-152 mm ebadında lal renkli çift çizgi cetvellidir. 91a/81a-93a/83a varakları, iki ve üç sütunludur. 93b/83b-97b/87b varaklarında ise çizelgeler vardır.

71 Diğer varaklar 254-273 x 142-150 mm ebadında açık kırmızı renkli çift çizgili cetvelli ve çift sütunludur. 106b/250b varak cetvelinin sol tarafı tek çizgilidir.

72 XVII. Yüzyılın ikinci yarısında doğmuş ve 1738'de İstanbul'da vefat etmiş olan Nahîfî Efendi'nin asıl adı, Mehmed Süleyman'dır. Manzum mesnevî tercümesiye tanınan bu divan şairi, genellikle mevlevîlikle ilgili pek çok manzum ve mensur eser vermiştir. Gazel ve şiirlerinden bazıları ilahi ve şarkı formunda bestelenmiştir (Uzun, 2006, s. 297-299).

73 İlgili satırların başındaki "Güfte-i Nahîfî Efendi" ifadesinden, beyitlerin ilahi ya da şarkı formunda bestelenmiş olduğu anlaşılmaktadır.

74 X. yüzyılda yaşamış ve asıl adı Seyyid Muhammed b. Muhammed Arîz el-Bağdâdî olan Vefâiyye tarikatinin kurucusudur. Daha çok heteredoks bir yapısı olan Vefâiyye tarikatı, halifeler aracılığıyla Irak, Suriye, özellikle de Anadolu'daki konar-göçer Türkmenler arasında çok yayılmış ve Anadolu'daki sosyal-dinî hareketlerde büyük rol oynamıştır (Ocak, 1994, s. 347-348).

75 Nahîfî Efendi'nin beyitleri ile 145b/258b'de kime ait olduğu belli olmayan iki beyit, talikle yazılmıştır. 144b/257b ve 145a-b/258a-b'de derkenarlar eklenmiştir.

76 Varaklar, 278-283 x 152-153 mm ebadında lal renkli çift çizgi cetvelli ve çift sütunlu cetvellidir. 
hikmetli sözleri, gelmiş geçmiş bütün peygamberlerden bilinenlerin isimleri ve sayıları vardır. Hat, yaklaşık 45 derece eğimli nesihtir. 192b/252b varağında derkenar vardır. Başlıklar, dikkat çekilmek istenen kelimeler, bazı kelimelerin altına çizilen çizgiler, bazı isimler, virgüller, vakfeler ve Yll varak numarası, açık kırmızı, pembeye dönük kırmızı ve koyu pembeye dönük kırmızı mürekkeplidir. ${ }^{77}$

Bâbu Mataru'n-Nîsân (vr. 187a/211a): Varağın sağ sütununda "Bâbu Mataru'n-Nîsân" başlıklı bu bölümde, nisan yağmurunun önemi ve şifası hakkında Hz. Muhammed ve dört halifeden rivayet edilen sözler ve okunacak dualar yazılıdır. Hat, nesihtir. "Bâb" kelimesi ile nokta şeklinde vakfeler, açık kırmızı mürekkeplidir. ${ }^{78}$

\section{Namazın Farzları, Ayetler, Dualar, Virdler, Oruç Fidyesi, Kurban Vekâleti: ${ }^{79}$}

64a-66b: Abdest duaları, namazın farzları, virdlerle ilgili dualar ve bazı meselelerin çözümü için dualar yazılıdır. Hat, harekeli nesihtir. Başlık, dikkat çekilmek istenen kelimeler ve vakfeler, pembeye dönük kırmızı mürekkeplidir. 64a'da, üç çizgili yarım daire şeklinde çok basit bir serlevhası vardır. 65a'da ise talik yazı ile namazın farzlarını açıklayan ve muhtemelen başka biri tarafından eklenmiş bir derkenar bulunur. ${ }^{80}$

67a-69b: Hz. Muhammed'in bir virdi, Âyete'l-Kürsî okumanın faziletleri, çeşitli hastalıklardan, borçtan kurtulmak, kazâya kalan namazlar vb. için okunacak dua ve âyetler ile "Yedi Âyet"81 ve oruç fidyesiyle ilgili bilgiler yazılıdır. Hattın büyük kısmı, özellikle âyetler harekeli nesihtir. Başlıklar, dikkat çekilmek istenen kelimeler, vakfeler ve bazı derkenarlar, pembeye ve koyu pembeye dönük kırmızı mürekkeplidir. ${ }^{82}$

9b-10a: Bir istihâre duası ile kurban vekâleti ve kesim sırasında okunacak duâlar vardır. Hat, 9b'de talik; 10a'da harekeli nesihtir. Başlıkların çoğu açık kırmızı, bazıları lal mürekkeplidir. 83

Kahire-Kâbe Hac Güzergâhı ve Menziller (vr. 98b/88b): Başlı̆̆ında, Kahire'den Kâbe'ye (Mekke) hacca gidecek hacıların yol üzerinde uğrayacakları menzillerin isimleri, bazı açıklamalar ve menziller arası mesafelerin saat olarak süreleri yazılıdır. Ancak bu varak, 22. menzil olan $\mathrm{Nayt}^{84}$ ile sona ermektedir. Sonraki varak ise boştur. ${ }^{85}$ Hat, ekseriyeti harekeli nesihtir. Başlık, menzil numaraları, dikkat çekilmek istenen

Varaklar, 272-274 x 148-150 mm ebadında açık kırmızı renkli çift çizgi cetvelli ve çift sütunlu cetvellidir.

Varaklar, 282 x 148 mm ebadında siyah renkli çift çizgi cetvelli ve ortası yeşil çift sütunlu cetvellidir.

vr. $64 a-69 b, 9 b-10 a$.

Varaklar, 265-280 x 155-160 mm ebadında, pembeye dönük kırmızı renkli çift çizgi cetvelli ve çift sütunlu cetvellidir.

1 Muaz b. Cebel'den rivayet olunan, tehlike, korku vb. durumlara karşı okuyanı koruyan Kur'an-1 Kerim'deki bu yedi âyet şunlardır: Tevbe 9: 51; Yunus 10: 107; Hûd 11: 6, 56; Ankebûd 29: 60; Fâtır 35: 2; Zümer 39: 38 (Hatipoğlu, 2016).

82 Varaklar, 272-285 x 155-160 mm ebadında, koyu pembeye dönük kırmızı renkli çift çizgi cetvelli ve çift sütunludur. 67b'nin üst cetvel çizgileri, restorasyon sırasında kaplanan kâğıtla kapanmıştır.

83 Varaklar, 274, 275 x 145, 150 mm ebadında, üç açık kırmızı arasına bir yeşil çizgi cetvelli ve açık kırmızı renkli çift çizgi cetvellidir.

84 تَبط . Bu menzil, XVIII. yüzyılın ilk yarısında vefat etmiş Nâbi ve Nâtık adlı şairlerin katıldıkları hac yolculuklarını kaleme aldıkları Tuhfetü'l-Harameyn isimli seyahatnamede zikredilmez (Aksoyak, 2002, s. 13). Nâbi, Kahire'den Mekke'ye kadar sadece önemli gördüğü menzillerin ismini verirken; daha fazla menzile yer veren Nâtık, Havra menzilinden sonra gelen BN'ndaki Nayt menzilini "Nâr Vâdîsi" olarak kaydetmiştir. Nâtık'a göre BN'nda olmayan Nayt/Nâr Vadisi'nden Kabe'ye kadarki menziller ise Hudeyre, Yenbûa, Bedr-i Huneyn, Sebî-i Mahsen, Râbia Eşmesi, Kadîde ve Asfân ve Mekke'dir (Nâbi'nin eserinde: Mısır Akabesi, Bedr-i Huneyn, Râbı̆̆, Mekke) (Aksoyak, Aynı yer).

$85 \mathrm{Bu}$ boş varak, sıraya aykırı bir şekilde Arabî rakamla 19 r olarak numaralandırılmışken, baştaki 1 silinerek 9 r yazılmıştır. Hemen altında günümüz rakamları ile kurşun kalemle sonradan yapılan numaralandırmada ise sıraya uygun olarak 99 yazılmıştır. 
kelimeler, vakfeler ve varak numarası ile sondaki ayak, koyu pembeye dönük kırmızı mürekkeplidir. ${ }^{86}$

Arap Atasözleri ve İlahi Aşkın Beş Mertebesi (vr. 192a/252a): Türkçeye çevrilmiş bazı Arap atasözleri ile ilahî aşkın beş aşamasına dair bilgiler bulunmaktadır. Hat, harekeli birkaç kelime dişında harekesiz nesihtir. Sağ sütun düz, sol sütun yaklaşık 45 derece eğik yazılmıştır. Başlıklar, dikkat çekilmek istenen kelimeler, çizgiler ve vakfeler, pembeye dönük kırmızı mürekkeplidir. ${ }^{87}$

Şeyhülislâm Ebussuud Efendi İle Bolevî Mustafa Efendi'nin Fetvaları:88 XVI. yüzyılın meşhur şeyhülislâmı Ebussuud Efendi ile XVII. yüzyılda yaşamış Bolevî Mustafa Efendi'nin ${ }^{89}$ çeşitli hususlarda yazdığı arz, mektup, vakfiye, fetvalar ve söz konusu hususlarla ilgili meselelere dair sorular ve cevaplardan örnekler vardır:

156a/183a-164a/210a, 171a/208a: Ebussuud Efendi'nin çeşitli konulara dair arz, mektup, vakfiye ve fetva suretleri yer almaktadır. Hat, nesihtir. İlk varak olan 150a/140a'da; üç açık kırmızı, bir yeşil renkli dört çizgili bir yarım daire ve yarım daire ile cetvel arasındaki köşebentlerin içinin açık kırmızı ve yeşil mürekkeple yazılmış" harfleriyle ${ }^{90}$ doldurulduğu basit bir serlevhası vardır. Varaklar ekseriyetle derkenarlıdır. Bazı varaklardaki satırlar, eğimli çizgilerle bölünmüş kısımlara eğik şekilde yazılmıştır. Serlevha hariç varak numaralarının çevresine, açık kırmızı renkli çift çizgili matlaplar konulmuştur. Başlıklarda, dikkat çekilmek istenen kelimelerde, bazı kelimelerin altına çizilen çizgilerde, bazı varaklarda konuları ayırmak için çizilen çizgilerde, fasıllarda ve vakfelerde; açı kırmızı, koyu pembeye dönük kırmızı, bayrak kırmızı ve yeşil mürekkep kullanılmıştır. ${ }^{91}$

109a/192a-115b/202b: Bolevî Mustafa Efendi'nin çeşitli hususlara ait sorulara verdiği cevaplar ve fetvaları yazılıdır. İlk varak olan 109a'da, çift sütun üzerinde iki yarım daire şeklinde açık kırmızı ve yeşil renk çizgili çok basit serlevhalar vardır. ${ }^{92}$ Hat, iki harekeli satır haricinde harekesiz nesihtir. Başlıklar, dikkat çekilmek istenen

Varak, 282 x 151 mm ebadında, lal renkli çift çizgi cetvelli ve çift sütunludur.

Varak, 272 × $150 \mathrm{~mm}$ ebadında açık kırmızı renkli çift çizgi cetvellidir.

88 vr. 156a/183a-164a/210a, 171a/208a (Muhtemelen orijinal şirazenin dağılması sonucunda karışmış ve yine muhtemelen restorasyon sırasında ait olduğu konuya bakılmayarak 170b/138b varağının arkasına konulmuş, dolayısıyla da sonradan yapılan numaralandırmada 171 rakamını almıştır), 109a/192a-115b/202b.

89 Padişah IV. Mehmed'in saltanatında görev yapmış 39. Osmanlı şeyhülislâmıdır. Müderrislik, İstanbul kadılı̆̆ı, Anadolu ve Rumeli kazaskerliğinden sonra 1657-1659 yıllarında şeyhülislâmlık yapmış, 1675'de Kahire'de vefat etmiştir. Takvâ sahibi, adil, birçok ilimle birlikte özellikle fıkıh ilminde ihtisas sahibidir. (Sicill-i Osmânî, C. IV, 1996, s. 1151; İpşirli, 2006, s. 295-296).

90 Cemalnûr Sargut'a göre İslâm tasavvufunda "mim" harfinin çeşitli anlamları vardır. Mim, işitme fiilinin ortaya çıktı̆̆ı, sıfat bulduğu yer; varlıkların sözünü işitme mahallidir. Söz ile başlanır ve yine söze dönülür. Mim, şehadet mülk ve kahır âlemindendir. Benzerlerinden farklı ve üstün konumda olmayı işaret eder. Allah'ın irade ve emrinin kul tarafından işitilip uygulanması demektir (Sargut, 2009, s. 14-15).

91273, 275, 277, 280 x 147-148, 150-153, 155-157 mm ebadında olan varaklardan; 156a/183a-157b/184b, 161a/188a-162b/190b varakları, yeşil (dikey) ve açık kırmızı (yatay) mürekkepli çift çizgi cetvelli ve sütunsuz; 158a-b/187a-b varakları, ortası açık kırmızı çift sütunludur. 159a/197a-160a/194a, 171a/208a varakları ise siyah renkli çift çizgi cetvelli ve ortası yeşil çift sütunludur. Ayrıca bazı cetvellerin türleri ile renklerindeki farklılığa ve Arabî varak numaralarının ardışık olmayışına bakılırsa, varak sıraları ve numaralarının restorasyon sırasında karıştığı anlaşılmaktadır.

92 109a/192a-112a/199a varakları, açık kırmızı mürekkepli çift çizgi matlaplıdır. 110a/193a, 111b/197b ve 114a/201a varakları derkenarlıdır. 
kelimeler, bazı kelimelerin altına çizilen kısa ve uzun çizgiler ve vakfelerin ekseriyeti açık kırmızı, kısmen de koyu pembeye dönük kırmızı mürekkeplidir. ${ }^{93}$

Şam, Mısır ile Doğunun ve Yedi İklim'in Önemli Şehirleri, Güneş Sistemindeki Gezegenlerin Hareketleri: ${ }^{4}$

89b/79b-90b/80b: Çeşitli hadis râvilerinin rivayetleriyle Şam'ın (Dımaşk) diğer şehirlerden üstün özelliklerinin anlatıldığı tipik bir şehir faziletnamesi ${ }^{95}$ vardır. Bu faziletname, Göynüklü Ahmed Efendi tarafından büyük bir ihtimalle "Fazîletü'şŞâmü'ş-Şerîfe" adlı bir eserden kopya edilmiş ya da derlenmiştir. Hat, harekesiz bazı kelimeler hariç 29 satırlı harekeli nesihtir. Peygamber ve râvi isimleri ile dikkat çekilmek istenen kelimeler, bazı kelimelerin altına çekilen kısa çizgiler ve vakfeler, pembeye dönük kırmızı mürekkeplidir. ${ }^{96}$

139a/121a: Mısır ve Doğu ülkelerinin diğer memleketlerden üstünlükleri, "ekâlîm-i seb'a" denen yedi kıta/yedi iklimdeki şehirler ve dünya üzerindeki kara parçalarının oluşma evreleri hakkında bilgiler vardır. Hat, nesihtir. Başlık, dikkat çekilmek istenen kelimeler ile bazı kelimelerin altına çizilen çizgiler, virgüller, vakfeler ve Arabî varak numarası, pembeye dönük kırmızı mürekkeplidir.97

140b/122b-142b/124b: Güneş sistemindeki gezegenlerin ve dünyanın doğudan batıya üç büyük yörünge hareketi, Osmanlı İmparatorluğu ve İslâm dünyasının en önemli şehirleri, İtalyan şehirleri olan Roma, Venedik ve Cenova'nın İstanbul'a uzaklıkları ve "mil" mesafesinin Osmanlı İmparatorluğu'nda kullanılan uzunluk ölçüleriyle uzundan kısaya karşılıklarına dair açıklamalar bulunmaktadır. Ayrıca 140b/122b-141a/123a varaklarında, pembeye dönük kırmızı mürekkeple çizilmiş yaklaşık $30 \mathrm{~mm}$ çapında üç çizgili dairenin içinde "Kostantiniyye İstanbul Halîc" yazılıdır. Hat, 30-41 satırlı nesihtir. 140b/122b'de bir derkenar vardır. Başlık, dikkat çekilmek istenen kelimeler, virgüller, vakfeler ve Arabî varak numaraları, koyu pembeye dönük kırmızı mürekkeplidir. ${ }^{98}$

\section{Osmanll-Avusturya Sınır Civarındaki Önemli Kaleler ve Yollar:99}

74a/64a: Varak ortasında bir daire şeklinde gösterilen Vidin kalesinin konumu ve fizikî özellikleri hakkında bilgi verilir.

74b/64b: İkisi Edirne-Niğbolu, biri de Şipka-Niğbolu olmak üzere üç yol güzergâhı vardır. Bu güzergâhlar üzerindeki menziller, Niğbolu daire içinde ortada olmak üzere "Y" harfi şeklinde üç kol hâlinde yazılmıştır.

99b-100a/93b-94a: Daire çizimlerinin içinde, Belgrad kalesinden itibaren Bosna'ya kadar Tuna ve Sava nehir yolu üzerindeki önemli menziller, kaleler ile Bosna

270, 275, 280 x 150, 155 mm ebadındaki varaklardan 109a/192a-112b/199b varakları, gri renkli çift çizgi cetvelli ve ortası yeşil çift sütunlu, 113a/200a-115b/202b varakları ise koyu pembeye dönük kırmızı renkli çift çizgi cetvelli ve çift sütunludur (vr. 115b/202b sütunsuzdur).

94 vr. 89b/79b-90b/80b, 139a/121a, 140b/122b-142b/124b.

95 Şehir faziletnâmeleri hakkında ayrıntılı bilgi için bkz. Kandemir, 1995, s. 531; Yılmaz, 2017, s. 370-379; Ateş, 1978, s. 5690.

96 Varaklar, 278-283 x 152 mm ebadında, lal renkli çift çizgi cetvelli ve çift sütunludur.

97 Varaklar, 277 x 153 mm ebadında lal renkli çift çizgi cetvelli ve çift sütunludur.

98 Varaklar, 275, $280 \times$ 150-153 mm ebadında, lal renkli çift çizgi cetvelli ve çift sütunlu cetvellidir.

99 vr. 74a-b/64a-b, 99b-100a/93b-94a, 166b/216b. 
Eyaleti'ndeki önemli kalelerin yazılı olduğu bir güzergâh vardır. Ayrıca bazı menzil ve kalelere dair uzun derkenarlar ve açıklamalar vardır. ${ }^{100}$ Hat, nesihtir. Dikkat çekilmek istenen ve altına kısa çizgi çekilen kelimeler, güzergâhı göstermek için çizilen daire ve çizgiler, vakfeler ve Arabî varak numarası, lal mürekkeplidir. ${ }^{101}$

166b/216b: Bosna Eyaleti dahilinde ve Saraybosna civarındaki önemli kaleler, Belgrad kalesi ve Avusturya ile Venedik'in elindeki bazı kalelerin saat olarak Bosna'ya uzaklıklarını ve kalelerle ilgili açılamaları kabaca gösteren bir kroki bulunmaktadır. Hat, nesihtir. Başlıklar, saatler ve krokinin çizgileri, koyu pembeye dönük kırmızı mürekkeplidir. ${ }^{102}$

Sene-i Kebîse ve Vakfe Vakitlerini Hesaplama Formülleri, Aşura Duaları:103

102a/113a-103a/114a: Varağın üst kısmında, dört yılda bir şubat ayının 29 gün (bir gün fazla) olması nedeniyle ortaya çıan ve Osmanlı Devleti'nin idari işlerde ay yılını (hicrî yıl), mali işlerde ise güneş-ay yılının bir kombinasyonu olan malî yılı kullanmasından kaynaklanan "sene-i kebise/artık yıl/sıvış yılı" (Sahillioğlu, 1967, s. 7588) denilen yıl farkının ve gelir-giderlerin tahsil ve ödemelerde yarattığı karışıklığa çözüm olması için geliştirilen bir formülün genel açıklaması vardır. Ayrıca formülün her birinde iç içe daireler bulunan iki büyük daire (dâire-i kebîse) içinde uyarlaması da bulunmaktadır. Ancak kırmızı mürekkeple çizilen bu dairelerin içinde yazılı olanlar, nem ya da başka bir sebeple neredeyse tamamen silinmiştir. Varağın alt kısmında ise "âşûrâ günü"104 ve sonraki iki gün okunacak dualar yazılıdır. Bir dua da derkenar olarak kaydedilmiştir. Hat, ekseriyeti harekeli nesihtir. Başlıklar, dikkat çekilmek istenen kelimeler, bazı harekeler ve vakfeler, açık kırmızı ve koyu pembeye dönük kırmızı mürekkeplidir. İki satır ve tarih ise griye dönük yeşil renklidir. ${ }^{105}$

103b/114b: Mecmua'nın sonraki sahiplerinden biri tarafından vakfe vakitlerinin doğru tespit edilmesine dair 1793-1794 tarihinde Kudüs'te yazılmış bir formül vardır. Hat, nesihtir. ${ }^{106}$

121a/103a-126a/108a: Kolay kesirli sayı hesaplamaları ve çok rakamlı sayıların çarpma ve bölme işlemleri, ağırlık, hacim vb. hesaplama formülleri ve açıklamalar bulunmaktadır. Hat, nesihtir. 121a/103a'da, açık kırmızı üç çizgili yarım daire şeklinde çok basit bir serlevhası vardır. Başlıklar, dikkat çekilmek istenen bazı kelime ve rakamlar ve Arabî varak numaraları, açık kırmızı ve koyu pembeye dönük kırmızı mürekkeplidir. ${ }^{107}$

Tarih: Rus (Moskov), Mora, Avusturya (Nemçe), Iran seferleri, Patrona Halil İsyanı, Tayinler ve Aziller, Önemli Olaylar:108 Göynüklü Ahmed Efendi'nin gözlemlerine ve

100 Müellifin yazı ve üslubunun dışında daha kalın ve daha geç dönemlerde kullanılan rık'a hatlı bazı açıklamalar, sonraki yıllarda eklenmiş olmalıdır.

101 Varaklar, 277, 280 x 151, 153 mm ebadında, lal renkli çift çizgi cetvelli ve çift sütunlu cetvellidir.

102278 x $147 \mathrm{~mm}$ ebadında siyah renkli çift çizgi cetvelli ve ortası yeşil çift sütunlu cetvellidir.

103 vr. 102a/113a-103b/114b, 121a/103a-126a/108a.

104 Hz. Nuh'tan itibaren bütün Samî dinlerde, hatta Cahiliye devri Arapları arasında da mevcut olan ve oruç tutulan hicrî Muharrem ayının onuncu günü (Yavuz, 1991, s. 24).

105 Varaklar, 258, 247 x 149, 148 mm ebadında, açık kırmızı renkli çift çizgi cetvellidir.

106 Varak, 256 x 147 mm ebadında, açık kırmızı mürekkepli çift çizgi cetvellidir.

107 270-275, 280 x 150-155 mm ebadındaki cetvellerin bir kısmı siyah çift çizgi cetvelli ve çift sütunlu; diğer kısmı ise koyu pembeye dönük kırmızı renkli çift çizgi cetvelli ve çift sütunludur.

108 vr. 72a-73b/62a-63b, 75a/65a, 178a-179a/217a-218a, 182a-b/230a-b, 176a-b/231a-b, 215b/300b-371b/474b. 
duyumlarına göre kaleme aldığı Prut Seferi, İsveç Kralı XII. Karl'ın (Demirbaş Şarl) ülkesine dönüşü, Mora, Nemçe, Rus, İran seferleri, Patrona Halil İsyanı, Padişah III. Ahmed'in tahttan inmesi ve I. Mahmud'un saltanatının başlaması, devlet kadrolarındaki tayinler ve aziller, sûr-i hümâyûnlar ve masrafları, sikke tashihi, kapıkullarına verilen ulufeler ve bahşişler, bazı ferman ve mektup suretleri, elçi kabulleri, şehzade doğumları, yangınlar, ziyafetler vs. ait kayıtlar vardır:

215b/300b-242a/333a: Ahmed Efendi'nin bizzat katıldığı 1711 Osmanlı-Rus Savaş1 (Moskov Seferi) ile 19 Şubat 1711-27 Haziran 1713 dönemine ait olaylar yazılıdır. ${ }^{109}$ Bölüm, 215b/300b'nin sağ sütununun ilk üç satırında olan "Bin Yüz Yigirmi Üç Senesinin Māh-i Muharremü'l-Harām'ın Gurresinde Vāki' Olan Sefer-i Hümāyūn-1 Sa'ādet-Makrūnu Beyān Eder" başlığı ile başlar ve 248a/333a varağının ortasında, İsveç kralının ülkesine gitmek üzere hareket ettiği ile ilgili haberin ve mektubun Sadrazam Damat Ali Paşa'ya ulaştığına dair 18. satırla sona erer. $B N$ 'nda bu bölümün dört varağ1 (sekiz sayfa) eksik, bir varağı ise boştur. ${ }^{110}$ Ayrıca Osmanlı ordusunun Prut nehri kenarında Rus ordusunu kuşatmasına dair müellif ya da bir başkası tarafından çizilmiş basit, renkli bir harita vardır. ${ }^{111}$ Hat, ekseriyetle nesihtir. Menziller, saatler ve bazı harfler, muhtemelen maliye kâtipliğinden gelme bir alışkanlıkla siyakatla yazılmıştır. Bazı varaklar harekeli ve derkenarlıdır. ${ }^{112}$ Konu başlıkları, dikkat çekilmek istenen kelimeler, altı çizilen bazı kelimeler, tarihler, menziller ve menzil saatleri, bazı harekeler, virgüller ve vakfeler, açık kırmızı ve koyu pembeye dönük kırmızı mürekkeplidir. ${ }^{113}$ Bazı varaklar cetvellidir. ${ }^{114}$

243b/334b: Boş varağın alt kısmına, Mora Seferi hazırlıkları çerçevesinde Osmanlı ordusun geçeceği Yenişehir-Körfös güzergâhı üzerindeki menziller ile yolun fizikî şartları ve temizlenmesine dair bilgiler vardır. ${ }^{115}$ Hat, nesihtir. Menziller ve saat, koyu pembeye dönük kırmızı mürekkeplidir.

244a/335a-269a/359a: 8-18 Aralık 1714-26 Kasım 1715 tarihleri arasında; Mora Seferi için kapıkulu ocakları ile Anadolu ve Rumeli'nin çeşitli kazalarındaki askeri kuvvetlere yazılan sefere çağrı hüküm suretleri, Karadağ İsyanının bastırılması ve mevâcib

109 Ahmed Efendi'nin bu bölümünde tuttuğu kayıtlar, RN'nın tamamı (1b-138a) ile BN'nın 215b(300b) ile 242a/248a(333a) arasındaki 34 varaklık kısmını ihtiva etmektedir. Ancak BN'nın söz konusu bölümünde, 220a/305a(315a)'dan itibaren sonradan eklenmiş olan rakamların; 221a/306a'dan itibaren de 227a/312a, 229a/314a, 232a/317a, 234a/319a ve 235a/320a numaralı varakların rakam sırası karışmışıı. Bazı varakların ise yeri değişmiş̧tir.Söz konusu varaklardan 304b'den sonra 305a olması gerekirken 307a vardır. 305a, daha ilerideki sayfaların arasına karışmıştır. Yine sırası karışmış olan $305 \mathrm{~b}$, ileride 365a/317a varağının sol tarafına girmiştir. 306a, 307a olarak numaralandırılmış, 310b ise 320a'nın sağ sayfasına girmiştir. 311a-b ise yerinde yoktur. 312b, 314b'nin yerindedir. 313a-b boştur. 315b, 317b'nin yerindedir. 316ab, boştur. 317b, 321a'nın sağ sayfasına girmiştir. 318a-b, boştur. Buna rağmen yazmanın tümü ayrıntılı olarak incelenerek ve $R N$ ile karşılaştırılarak yerleri değişen varaklar olması gereken yerlerine alınmış, Arabî ve sonradan eklenen varak numaraları da üzeri çizilip doğrusu yazılmak suretiyle düzeltilmiştir.

110 vr. 227a-b/312a-b, 229a-b/314a-b, 232a-b/317a-b ve 234a-b/319a-b eksiktir. 241b/326b, boştur.

111 Yeri karışarak 305a/365a varağının arka yüzüne girmiş olan bu kuşatma haritası, $R N$ 'daki yeri ve olayların sırası esas alınarak 219b/304b-220a/305a varağından sonraki 220b/305b-221a/306a varağına alınmıştır.

112 vr. 230a/315a-231b/316b, 233a-b/318-b, 235a/320a-248a/333a varaklar1 harekelidir. 215b/300b-220a/305a, 221b/306b varaklar1 ise harekesizdir. 219b/304b, 221b/306b, 224b/309b-226b/311b, 230b/315b, 235b7320b-240b/325b, 242b/327b248a/333a varakları ayaklıdır. 221b/306b ve $242 b / 327 b$ 'de derkenar vardır.

113 vr. 244a/329a'daki 30. satıın tamamı ile 247a/332a'nın 22. satırının yarısı ise griye dönük yeşil mürekkeple yazılmıştır.

114 vr. 215b/300b-220a/305a ve 221b/306b-225b/310b varakları, 262-280 x 145-153 mm ebadında açı kırmızı ve pembeye dönük kırmızı renkli çift çizgi cetvellidir. 215b/300b, ayrıca ortası yeşil çift sütunludur.

115 Mora Seferi menzilleri ve menzillerin fizikî özellikleri için bkz. Ertaş, 2007, s. 31-38. 
ödemeleri hakkında bilgiler ile Ahmed Efendi'nin ordu-yı hümâyûnun Mora sefer güzergâhı üzerinde uğradığı menziller ve çeşitli kazalar hakkındaki gözlemlerine, kale kuşatmalarına ve Venedik kuvvetleriyle çarpışmalara, fetihlere, azil/tayinlere ${ }^{116}$ ve ordunun dönüşüne dair tuttuğu kayıtlar bulunmaktadır. Hat, nesih olmakla birlikte menzil kelimeleri siyakatla yazılmıştır. Varaklar, 28-32 satırlı ve ayaklıdır. Yazılışı aynı anlamı farklı olan kelimeler, dikkat çekilmek istenen kelimeler ve yabancı dile ait yer isimleri, harekeli yazılmıştır. Bazı varaklar derkenarlıdır. ${ }^{117}$ Başlıklar, dikkat çekilmek istenen kelimeler, bazı kelimelerin altına çekilen çizgiler, menziller, saat olarak menziller arasındaki mesafeler, tarihler, rakamlar ve vakfeler, ekseriyetle açık kırmızı, pembeye dönük kırmızı, lal mürekkepli ve kısmen griye dönük yeşil mürekkeplidir.

72a/62a: 1723-1746 Osmanl-İran savaşlarında, ${ }^{118}$ Isfahan üzerine yürüyecek Osmanlı kuvvetlerinin Üsküdar'dan Kirmanşah'a kadar sefer güzergâhındaki 87 menzilin isimleri ve menziller arasındaki yürüyüşs süreleri yazılıdır. Ayrıca sefer yürüyüşü sırasında askerlerin yiyecek ihtiyaçlarının karşılanması için hazırlanan mevkufat defteri doğrultusunda miktar ve sayıları belirlenen hububat ve canlı hayvanların, güzergâh civarındaki halkın vergilerine karşılık olarak söz konusu menzillerde hazır bulundurulmasına dair 17 Şubat 1727 tarihli bir ferman sureti bulunmaktadır. Başlık ve saatler, siyakat; menzil isimleri, derkenar ve ferman sureti, divanî hatla yazılmıştır. Saatler, menzil açıklamaları, "yekûn" satırı, tarihler ve vakfeler, koyu pembeye dönük kırmızı mürekkeplidir. ${ }^{119}$

72b/62b-73a/63a: 12 Nisan 1727 tarihinde Üsküdar'dan Tebriz ve Hemedan'a sefere çıkan bir başka Osmanlı kuvvetinin yürüyüş güzergâhı üzerindeki menziller ile Bağdad Valisi Ahmed Paşa'nın ordusuyla Hüveyze'ye gidişine kadar olan menziller ve mesafe süreleri yazılıdır. Başlıklar divanî, menziller ile saatler harekeli divanî hatla yazılmıştır. Saatler, dikkat çekilmek istenen kelimeler, bazı tarihler, menziller ve menziller altına çizilen kısa çizgiler, koyu pembeye dönük kırmızı mürekkeplidir. ${ }^{120}$

295b/385b-330/418b: Tayinler, aziller, elçi kabulleri, elçi uğurlamaları, ziyafetler, sûr-i hümâyûn,, ${ }^{121}$ Cebecibaşının sûr-i hümâyûn için hazırlattığ1 çeşitli fişeklere ait masraf defterinin sureti, müşavereler, İran ile 1724-1726 yıllarındaki savaşlarda fethedilen ve kaybedilen kaleler, İran'a yapılan seferlerde ordunun geçeceği menzillerde belli miktarlarda erzak hazırlanması, İran'da yönetime hakim olan kişilerle siyasi ilişkiler, Isfahan'a hükmeden Eşref Han'ın elçisine verilen mektup sureti, ilginç olaylar, ulufe ödemeleri, devlet hazinesinde yapılan usulsüzlükler, sikke tashihi, Zeynep Sultan ve Ayşe Sultan'ın nikâhlanmaları, İran'da Şah Tahmasb'a karşı alınan yenilgiler üzerine 27 Temmuz 1730'da İran'a tekrar sefer kararı alınması, Patrona Halil

116 Meselâ, o sıralarda rakibi Köse İbrahim Ağa'nın aleyteki faaliyetleri sonucunda 26 Safer 1127/3 Mart 1715 tarihinde tenzil-i rütbe ile silahdar kâtipliğine tayin edilmiş olan ilk resmî vak'anüvis Naimâ Efendi, Mora Seferi'nde himayesinde olduğu Sadrazam Damat Ali Paşa tarafından Palatmana menzilinde eski görevi olan Anadolu muhasebeciliğine getirilmişti: "Silahdār kātibi olan Na'ìmā Efendi, Anadolu muhāsebeciligi ihsān buyurulup": BN, yz. 1209, vr. 251b/342b. Keza bkz. İpşirli, 2006, s. 316-318.

117 vr. 249a/340a, 252b/343b, 256a/347a, 257a/348a.

118 Bu savaşlar için bkz. Uzunçarşıll, 1982, s. 175-203, 218-234, 299-309.

119 Varak, 278 × 152 mm ebadında, koyu pembeye dönük kırmızı mürekkepli çift çizgi cetvelli ve çift sütunlu cetvellidir.

120 Varaklar, 280 x 150-155 mm ebadında, koyu pembeye dönük kırmızı renkli çift çizgi cetvelli ve çift sütunlu cetvellidir.

121 Padişah III. Ahmed'in dört şehzadesi ve 3902 çocuğun sünneti ile eski padişah II. Mustafa'nın iki kızının düğün törenleri şerefine 18 Eylül 1720 tarihinde başlayan ve 23 gün süren muhteşem şenlikler (Bkz. Atıl, 1999). 
İsyanı, I. Mahmud'un tahta geçmesi, hazineden kapıkulu ocaklarına dağıtılan bahşiş ve ulufe rakamları, İran'a tekrar sefer açılması, 1731 yılında yapılan savaşlarda Şah Tahmasb'ın kuvvetlerinin mağlup edilerek bazı yerlerin geri alınması, İran'la antlaşma imzalanması, Nadir Şah'ın antlaşmaya karşı çıkmasıyla İran savaşının yeniden başlaması, İstanbul'da çıkan yangınlar vs. dair kayıtlar vardır. Hat, nesihtir. Eşref Han'ın elçisine verilen Arapça mektup ve bazı kelimeler harekelidir. Ekseriyetle 28-31 satır olan varakların sonları ayaklıdır. Bazı varaklar derkenarlıdır. ${ }^{122}$ Başlıklar, dikkat çekilmek istenen kelimeler, bazı kelimelerin üzerine çizilen çizgiler, tarihler, bazı rakamlar ve vakfeler, pembeye ve koyu pembeye dönük kırmızı mürekkeplidir.

270a/360a-295a/385a: 28 Şubat 1716 tarihinden, 20 Ekim 1718 tarihine kadar Osmanlı ordularının Avusturya üzerine çıktığı seferler ${ }^{123}$, gün gün hatta saat saat sefer güzergâhı üzerinde geçilen menziller, menzillerin coğrafî özellikleri, elçi kabulleri, yaşanan olaylar, düşmanla çarpışmalar, çeşitli kadrolara tayinler ve aziller, verilen hediyeler vb. konular, seferlere katılan Göynüklü Ahmed Efendi tarafından kaydedilmiştir. Hat, harekeli yazılan bazı satırlar, kelimeler ve yer isimleri dışında harekesiz nesihtir. Menziller ve "meks"ler, siyakatla yazılmıştır. Varaklar, genellikle 2836 satırlı ve ayaklıdır. Bazı varaklar derkenarlıdır.124 Başlıklar, menziller, menziller arası mesafe süreleri, bazı meksler, dikkat çekilmek istenen kelimeler, bazı kelimelerin altına çekilen çizgiler, tarihler, bazı notlar, bazı rakamlar ve vakfeler, ekseriyetle pembeye dönük kırmızı mürekkepli ve nadiren griye dönük yeşil mürekkeplidir.

73b/63b: Sağ sütunda; Serdâriekrem İvaz Mehmed Paşa ve emrindeki Osmanlı ordusunun Avusturya seferine çıkması (1737), seferde Anadolu muhasebecisi olarak Vidin'de bulunan Göynüklü Ahmed Efendi'nin erzak sıkıntısının giderilmesi için Tuna kıyılarından zahire toplaması ve bunların gemilerle Adakale'ye ve ihtiyaç duyulan yerlere gönderilmesine dair olaylar anlatılmaktadır.

73b/63b sol sütun ve 75a/65a: Ahmed Efendi'nin, bizzat sadrazamdan öğrendiği şekilde kaydettiği Osmanlı-Avusturya barış görüşmelerine dair gelişmeler yazılıdır. ${ }^{125}$

178a-179a/217a-218a: Osmanl1-Avusturya savaşlarında, Bosna Valisi Hekimoğlu Ali Paşa'nın 1737 yılının yaz ve sonbahar aylarında kadın ve çocukların da katıldı̆̆ Usturumca kalesi savunmasındaki büyük başarısı ve ardından emrindeki Bosna kuvvetleriyle Avusturya ordularını bozguna uğratarak Bosna'yı işgalden kurtarmasına dair olaylar ${ }^{126}$ anlatılır. Hat, siyakatla yazılan menziller dışında nesihtir. ${ }^{127}$ Başlıklar, dikkat çekilmek istenen kelime/cümleler, tarihler, vakfeler, bazı varak numaraları, bazı çizgiler ve Vidin kalesi ile Niğbolu'ya ait daire çizgileri ve menziller, koyu pembeye dönük kırmızı mürekkeplidir. ${ }^{128}$

122 vr. 316a/404a, 318a/406a, 320b/408b, 321a-b/409a-b, 322b/410b, 323a/411a, 324a/412a, 325a/413a.

123 Bu seferler için bkz. Uzunçarş1ll, 1982, s. 109-142.

124 vr. 277a/367a ve 293a/383a.

125 Bu konunun sayfaları restorasyon sırasında karışmıştır. 73b/63b'nin sol sütununda başlayan bölüm, sayfa sonundaki ayağa göre bir sayfa atlayarak 75a/65a'da sona ermektedir. Dolayısıyla 75a/65a'nın varak numarası 74a/64a olmalıdır.

126 Hekimoğlu Ali Paşa'nın Avusturyalılarla mücadelesi için bkz. Uzunçarşıllı, 1982, s. 274-277.

127 vr. 178b/217b-179a/218a, 30-31 satırlıdır. 176a/231a, 178a/217a ve 179a/218a varakları ise matlaplıdır.

128 Varaklar, 272, 275 x 147-150, 155 mm ebadında, koyu pembeye dönük kırmızı renkli çift çizgi cetvelli, çift sütunlu ve siyah renkli ortası yeşil çift sütunlu çift çizgi cetvellidir. 
182a-b/230a-b: 11 Mayıs 1732'den, 10 Ağustos 1746 tarihine kadar sadaret makamına tayin edilen kişiler ve sadrazamlık sürelerine dair bilgi verilmiştir. Ayrıca 182a/230a'nın sağ sütununun en altında, Bâb-1 Seraskerî'ye ${ }^{129}$ ulemadan iki naibin atandığına dair 26 Ocak 1837 tarihli sonradan eklenmiş rık'a hatlı bir kayıt vardır.

176a-b/231a-b: 24 Ağustos 1747 tarihinden itibaren vezirlerin azil ve tayinleri ile ilgili açılamalar vardır. Konu ile ilgili son kayıt, Trabzon Valisi Hekimoğlu Ali Paşa'nın sadrazamlığa tayini dolayısıyla 27 Mart 1755'de Üsküdar'a gelişine aittir. Hat, nesihtir. 182a/230a varağı matlaplıdır. Başlıklar, dikkat çekilmek istenen kelime/cümleler, tarihler, vakfeler, bazı varak numaraları ve bazı çizgiler, koyu pembeye dönük kırmızı mürekkeplidir. ${ }^{130}$

331a/419a-353a/452a, 358b/460b-371b/474b: Ordu-yı hümâyûn ve donanmanın 1736 yılında Rus (Moskov) seferine hareketi, karada ve denizde savaşlar, elçi kabulleri, elçi tayinleri, devlet kadrolarında tayinler ve aziller, meşveretler, müşavereler, kıtlık ve yenilgi söylentileri, barışı bozarak Osmanlı topraklarına saldıran Avusturya ile savaşın başlaması, dış siyasetle ilgili meseleler, gıda fiyatları, yeni yapılan kalyonun donanmaya teslimi, İstanbul'da asayişi bozan olaylar, ulufe ödemeleri, ziyafetler, 1740 yılının Aralık ayında İstanbul'da ağaçlar çiçek açmışken kar yağması, Ruslarla barış görüşmeleri ve antlaşma maddeleri, devlet erkânının çocuklarının sünneti, sürre ${ }^{131}$ eşyalarının taşınması, III. Ahmed'in kızı Esma Sultan'ın evlenmesi şerefine düzenlenen sûr-i hümâyûn, ${ }^{132}$ İran Şahı Nadir Şah'ın yenilgi haberinin yarattığı sevinç, güneş ve ay tutulmaları, 1749 yılı mart ayında yağan yoğun kar ve şiddetli fırtına yüzünden İstanbul'a gıda sevkiyatının aksaması ve yakacak sıkıntısı çekilmesi, ay tutulması, 1750, 1751, 1754, 1755, 1756 ve 1758 yıllarında İstanbul'da çıkan büyük yangınlar, sadrazam ve sultan validelerinin hacca gitmesi, 31 Temmuz 1752 tarihinde İstanbul'da meydana gelen deprem, Ayşe Sultan'ın vefatı, mevlid-i şerif, Padişah I. Mahmud'un vefatı ve III. Osman'ın tahta çıkması, donanmanın denize açılma ve geçit törenleri vs. anlatılır. Hat, ekseriyetle nesih (nadiren harekeli), kısmen divanî, bazı malî kelimeler ise siyakattır. Genellikle 27-31, 34-35 satırlı varakların sonları ayaklıdır. Bazı varaklar derkenarlıdır. ${ }^{133}$. Başlıklar, dikkat çekilmek istenen kelimeler, bazı kelimelerin altına çekilen çizgiler, bazı kelimelerin harekeleri, bazı tarihler, bazı rakamlar, derkenarların büyük kısmı, notlar ve vakfeler, pembeye dönük ve koyu pembeye dönük kırmızı mürekkeplidir.

\section{Tilsimlar: ${ }^{134}$}

82a/72a: Varağın üst yarısına çizilmiş basit bir at resmi ve resmin çevresinde, atı ve sahibini tehlikelerden koruyacağına dair yazılar ve tılsımlar vardır. Hat, nesihtir. ${ }^{135}$

129 II. Mahmud döneminden II. Meşrutiyet'e kadar Osmanlı kara kuvvetlerinin en büyük komutanının resmî makamı (Özcan, 1991, s. 364).

130 Varak 269, $270 \times 149,150 \mathrm{~mm}$ ebadında siyah renkli çift çizgi cetvelli ve ortası yeşil çift sütunlu cetvellidir.

131 Osmanlı padişahlarının, ileri gelenlere dağıtılmak üzere, Mekke ve Medine'ye gönderdikleri para ve armağanlara verilen ad.

132 Düğün.

133 vr. 331b/419b, 332a/320a

134 vr. 82a/72a, 102b/113b-103a/114a.

135 Varak, 277 x 148 mm ebadında, çift siyah çizgi cetvellidir. 
102b/113b: Varağın üst kısmına; biri $131 \mathrm{~mm}$, diğeri $90 \mathrm{~mm}$ çapında iç içe iki daire ve 19 mm çapında bir yarım dairenin içine, Kur'ân-ı Kerîm'deki toplam sure, ayet, kelime sayıları ile iman, tevhit, namaz, oruç, hac, zekat, sadaka, gaza, kardeş, yetim, haramiler, suçlular ve zina hakkındaki ayetlerin sayıları yazılmıştır. Varağın alt yarısında ise bir sene boyunca kılınan farz, sünnet, vitir ve cuma namazlarının rekat sayıları, dileklerin gerçekleşmesi için Hz. Muhammed'in çeşitli isimlerinin belli sayılarda yazılmasıyla hazırlanan bir tılsım ve Allah'ın Kur'ân-1 Kerîm'i andığı 55 isim bulunmaktadır. Hat, büyük kısmı harekeli olan nesihtir. Bir başlık, daireler ve yarım dairenin üç çizgisinden ikisi (biri griye dönük yeşil renkli), dikkat çekilmek istenen bazı satır, kelime, harekeler ve vakfeler, açık kırmızı ve koyu pembeye dönük kırmızıdır. Bazı satırlar, dikkat çekilmek istenen kelimeler ve bazı harekeler ise griye dönük yeşil mürekkeplidir. ${ }^{136}$

103a/114a: Varağın en altında, dış taraftaki $66 \mathrm{~mm}$ çapında büyük daire ve içindeki daha küçük çaplı iki dairede Arapça ve Türkçe yazılmış kelimeler ve sayıların olduğu bir tılsım bulunmaktadır. Hat, ekseriyeti harekeli nesihtir. Sayılar ve vakfeler, açık kırmızı renklidir. Dairelerin çizgileri ile içlerindeki yazılar, açık kırmızı ve griye dönük yeşil mürekkeplidir. ${ }^{137}$

Cifr/Cefri138 Ilmi ile Yazılmış Kasideler, Beyitler ve Sırlı Ayetler:139 Allah'ın Hz. Musa'ya indirdiği levhaların içinde bulunan ve nebilere, velilere, vâsilere mahsus "ilklerin ilmi"ni, Hz. Muhammed'in emriyle Hz. Ali'nin ezberlemesi ve bir hayvan derisine yazmasıyla ortaya çıktığı iddia edilen Cefr-i Câmi' (Cefr) ${ }^{140}$ adlı gizli bilgileri inceleyen Muhyiddîn-i Arabî'nin, gelecekte neler olacağına dair çıkardığı bilgileri yazdığı "kaside"nin istinsah edilmiş bir kopyas ${ }^{141}$ vardır. Hat, bir varak dışında ${ }^{142} 28-29$ satırlı harekesiz nesihtir (harekeli Arapça satırlar hariç). Başlıklar, ara başlıklar, dikkat çekilmek istenen kelimeler, bazı kelimelerin altındaki çizgiler, virgüller ve vakfeler, pembeye dönük kırmızı mürekkeplidir: ${ }^{143}$

147b/263b: Hz. Ali'nin kendi eliyle yazdığ1 iddia edilen ve gelecekten haber verdiğine inanılan Câmi '̈̈'l-Esrâr ve Ma ânî adlı kitaptaki ${ }^{144}$ beyitlerinden seçilen "beş beyit" (ebyât-1 hamse) bulunmaktadır.

148a/264a: İmam Gazzâlî'nin büyük sırlarla dolu olduğunu söylediği Kur'ân-1 Kerîm'deki dört surenin dört ayeti ile ilgili Arapça açıklamalar ve harekeli olarak yazılmış Bakara suresinin 246. ayeti yer alır. ${ }^{145}$

136 Varak, 258 x 149 mm ebadında, açık kırmızı renkli çift çizgi cetvellidir.

137 Varak, 247 x 148 mm ebadında, açık kırmızı renkli çift çizgi cetvellidir.

138 Arap alfabesinin günümüzdeki 28 harf sırasının denilen ve her birinin rakamsal değeri olan farklı bir sıraya göre dizilişi olan "ebced"i esas alarak, harf/rakamların çeşitli metotlarla kombinasyonu ve değerlendirilmesi yoluyla gelecekte vuku bulacak olaylar hakkında bilgi edinme. (Uzun, 1994, s. 68-70).

139 vr. 146a/261a-148a/263b, 165b/215b.

140 Cifr-i Câmi hakkında bkz. Kaplan, 2010, s. 85-86; Uluğ, 2017, s. 163-164.

141 vr. $146 a / 261 a-147 b / 263 b$.

142 vr. $148 a / 264 a$.

143 Varaklar, 262, 270-278 x 147-153 mm ebadında koyu pembeye dönük çift çizgi cetvelli, çift sütunlu ve siyah renkli çift çizgi cetvelli ve ortası yeşil çift sütunludur.

144 Şiîlerin, Hz. Muhammed tarafından Hz. Ali'ye yazdırıldığına ve Ehl-i Beyt'in gizli ilmi olduğuna inandıkları, içinde haram, helal vd. konularda insanların her türlü ihtiyacını karşılayacak gizli bilgilerin olduğu rivayet edilen bu kitap, Kitâb-ı Ali, Câmia, Sahîfe, Cefr, Mushaf-ı Fâtıma gibi isimlerle de anılır. (Kaplan, 2010, s. 75-89). 
165b/215b: Muhyiddin-i Arabî'ye atfen yazılmış, her iki sütunda iki satır olmak üzere şifreli dört mısra vardır. Kısmen nesih, çokça rık'a hat özelliği taşıyan bu misralar, aslen boş olan varağa muhtemelen müelliften sonraki yıllarda başka biri tarafından eklenmiş olmalıdır.

Kâimî'nin Manzumesi ve Bosna Müftüsü'nün Cifrli Risalesi: ${ }^{146}$

197a/280a-214a/299a: "Kâimî" mahlasını kullanan sufî şair Şeyh Hasan Bosnevî'nin, ${ }^{147}$ Osmanlı ordularının XVII. yüzyılın ikinci yarısında Venedik ve Avusturya ile yaptı̆̆ı savaşlara dair zaferler, yenilgiler, barışın bozulması, hudut boylarındaki insanların üzüntü ve sevinçleri, fethedilen ve düşen kaleler, fethedilmesi işaret edilen yerler, Osmanlı ordularının başındaki komutanlar, çarpışmaların ayrıntılı tasviri vb. konularda, karışık bir vezinle ve dervişâne bir tarzla yazdığı destansı uzun manzumeler ve bazı misralarda muhtemelen cifr ilmi ile geleceğe dair ebced formüllü tarihler vardır. Hat, yaklaşık 45 derece eğik yazılmış nesihtir. 198a/282a ve 212a/297a, derkenarlıdır. Başlıklar, dikkat çekilmek istenen kelimeler, mısralar, tarihler, virgüller, vakfeler ve bazı Arabî varak numaraları, koyu pembeye dönük kırmızı mürekkeplidir. ${ }^{148}$

137a-b/119a-b: XVIII. yüzyıl ortalarına doğru Avusturya'nın Osmanlı Devleti ile yaptığı anlaşmayı ${ }^{149}$ bozarak saldırı hazırlıklarına başlaması üzerine, Sofya müftüsünün çok yakında başlayacak savaşın gelişmelerine ve genel olarak Avusturya'nın mağlup olacağına dair 29 Haziran 1737 tarihinde cifr ilmi ile bulduğu ve kaydettiği bilgiler yazılıdır. Göynüklü Ahmed Efendi de düştüğü notta, istinsah ettiği bu bilgilerin hepsinin gerçekleştiğini belirtmiştir. Hat, 29-30 satırlı nesihtir. Başlık, dikkat çekilmek istenen ve altına çizgi çekilen kelimeler, tarih, Arabî varak numarası ve vakfeler, koyu pembeye dönük kırmızı renklidir. ${ }^{150}$

\section{Fuzuli'nin Gazeli, Tasavoufí Şiirler, Ebcedli Tarihler: ${ }^{151}$}

103a/114a: Varağın sol tarafında, Fuzulî'nin bir gazeli vardır.

183b/105b(145b): Dünya hayatının gelip geçici bir hayal, ahiret hayatının ise gerçek olmasından dolayı gaflete düşmemeye dikkat edilmesine dair birkaç Farsça beyit ve beyitlerin Türkçe açıklamaları bulunmaktadır. Aslen boş varakların talik ve ileriki yıllarda ortaya çıkan rık'a hatla yazıldığına bakılırsa, Ahmed Efendi'den sonraki yıllarda mecmua sahipleri ya da başka biri tarafından kaydedilmiş olmalıdır. ${ }^{152}$

185a-b/226a-b: Tasavvufî şiirler ve ebced hesabı ile düşürülen tarihler vardır. Hat, 103a/114a'da talik, diğer varaklarda nesihtir. Sonradan eklenmiş olan 185a/226a'daki

145 Önceki varaklardaki gibi başlı̆̆ın kırmızı mürekkeple yazılmayışı, vakfelerin olmayışı ve yazıların daha ileriki yıllarda ortaya çıkan rık'aya geçişin izlerinin görüldüğü bir nesih hatla kaleme alınmasına bakılırsa bu satırlar, müellif tarafından boş bırakılmış sayfaya sonraki bir dönemde başkası tarafından yazılmış olmalıdır.

146 vr. 197a/280a-214a/299a, 137a-b/119a-b.

147 XVII. yüzyılda yaşamış, Kâdirî, Halvetî şeyhliği yapmış, cifr ilmindeki maharetiyle meşhur, keramet sahibi bir zat olan Bosnalı mutasavvif şair (Erdoğan, 2004, s. 257-269).

148 261-277, 280 x 144-158 mm cetvel ebadındaki varaklardan 197a/280a-205b/290b varakları, açık kırmızı renkli çift çizgi cetvelli ve çift sütunlu; 206a/291a-214a/299a varakları ise açık kırmızı renkli çift çizgi cetvelli ve ortası yeşil çift sütunludur.

14921 Temmuz 1718 tarihli Osmanlı-Avusturya barış antlaşması (Pasarofça) (Uzunçarşılı, 1982, s. 144).

150 Varak, 275 x 150 mm ebadında, lal mürekkepli çift çizgi cetvelli ve çift sütunludur.

151 vr. 103a/114a, 183b/105b (145b), 185a-b/226a-b, 186b/220b.

152 Varak, 275 x 150 mm ebadında, siyah mürekkepli çift çizgi cetvellidir. 
derkenar ve 185b/226b'deki beyit ise rık'a ile yazılmıştır. 185a/226a, matlaplıdır. Başlıklar, dikkat çekilmek istenen kelimeler, virgüller, vakfeler ve Arabî varak numarası, pembeye dönük kırmızı mürekkeplidir. ${ }^{153}$

186b/220b: Muhtemelen mecmuanın sonraki sahipleri ya da başka biri tarafından kısmen cetvel dışına da yazılmış şiirler ve beyitler vardır. Hat, talikdir. ${ }^{154}$

Bilmeceler (vr. 191a-191b [sol sütun]/225a-b): Çeşitli bilmeceler ve cevapları, ebcedle düşürülen tarihler, tek satırlı muammâlar ${ }^{155}$ ve cevabî açıklamaları ile donanma kalyonları için yazılmış bir kaside vardır. Hat, nesihtir. 191a/225a, matlaplı ve derkenarlıdır. Başlıklar, bilmece cevapları, dikkat çekilmek istenen kelimeler, bazı kelimelerin altına konulan çizgiler ve Arabî varak numarası, pembeye ve koyu pembeye dönük kırmızı mürekkeplidir. ${ }^{156}$

Güzel Kadının Özellikleri (vr. 191b [să̆g sütun]/225b): Güzel kadınlarda olması gereken fizikî özellikler ve müelliften sonraki yıllarda başka birinin bu özelliklere düştüğü eleştiri notu yazılıdır. Hat, nesihtir. Başkası tarafından eklenen not, rık'a ile yazılmıştır. Başlıklar, bilmece cevapları, dikkat çekilmek istenen kelimeler, bazı kelimelerin altına konulan çizgiler ve Arabî varak numarası, pembeye dönük kırmızı mürekkeplidir. ${ }^{157}$

Hastalıklar İçin Şifalı Bitkiler, İlaç Terkipleri ve Macunlar (vr. 70a/65a, ${ }^{158}$ 353b/452b358b/460b): Çeşitli hastalıkların tedavisi için şifalı bitkiler, dikkatli kullanılması gereken bitkilerin isimleri, hastalıkların tedavisi için tavsiye edilen bitkisel ilaç terkipleri, macunlar ve hazırlanma usulleri vs. yazılmıştır. Hat, çoğunlukla nesih (nadiren harekeli), kısmen divanîdir. Başlıklar, dikkat çekilmek istenen kelimeler, bazı kelimelerin altına çekilen çizgiler, bazı tarihler, bazı rakamlar, derkenarların büyük kısmı, notlar ve vakfeler, pembeye dönük/koyu pembeye dönük kırmızı mürekkeplidir. Varakların bazıları cetvelli, bazıları ise derkenarlıdır. ${ }^{159}$

\subsection{Rado Nüshası $(R N)$}

Bu nüsha, $B N^{\prime}$ nın sadece 34 varaklık kısmını ihtiva eden geç tarihli bir nüshadır. Şevket Rado'nun, BN'nın eksik sayfalarının şahsî kütüphanesindeki bir el yazmasında bulunduğunu bildirdiği ve söz konusu eksik sayfaları çeviri yazı ile yayımladığı makalesi (Rado, 1987, s. 807-824) ile haberdar olduğumuz bu nüsha, daha sonra Yapı Kredi Kültür Sanat Yayıncılık A.Ş. Sermet Çifter Kütüphanesi'ne alınmıştır. Şu anda ise İstanbul Araştırmaları Enstitüsü (İAE) Yazma Eserler Kütüphanesi, Şevket Rado Yazmaları, nr. ŞR000614'de bulunmaktadır (İAE Yazma Eserler Kataloğu, 2014, s. 982983).

153 Varak, 272, 275 x 152 mm ebadında, siyah renkli çift çizgi cetvelli ve ortası yeşil çift sütunlu cetvellidir.

154 Varak, 264 x 145 mm ebadında, siyah renkli çift çizgi cetvelli, ortası açık kırmızı çift sütunlu ve açık kırmızı çift çizgi cetvellidir.

155 Manası gizli, güç anlaşılan söz, bilmece (Pala, 2014, s. 326).

156 Varak, 277 x 150 mm ebadında, siyah renkli çift çizgi cetvelli ve ortası açık kırmızı çift sütunlu cetvellidir.

157 Varak, 275 x 148 mm ebadında, siyah renkli çift çizgi cetvelli ve ortası yeşil çift sütunlu cetvellidir.

158 Eski Arabî varak numarası bu sayfadan itibaren karışmaya başlamış ve v•(70) olması gereken rakam, to (65) olarak kaydedilmiştir. Sonradan kurşun kalemle yapılan numaralandırma ise 70 olarak doğru yazılmıştır.

159 vr. 70a/65a, 275-280 x 152-170 mm ebadında lal renkli çift çizgi cetvelli ve çift sütunlu cetvellidir. 353b/452b-358b/460b varakları cetvelsizdir. Bu varaklardan 354b/455b, 355b/457b, 358b/460b dışındakiler derkenarlıdır. 


\subsubsection{Nüshanın Fizikî Özellikleri}

Yazma, $222 \mathrm{~mm}$ x $165 \mathrm{~mm}$ ebadındadır. Ciltlenmemiş olmakla birlikte, üzeri yeşil bez ile kaplanmış iki mukavva kapak arasında muhafaza edilmektedir. ${ }^{160}$ Şirâzesi dağılmıştır. Vr. 1b ile 138a arasındaki 138 varaktan meydana gelmektedir.

Nüshanın kâğıdı krem renkli, orta kalın, aharlı, su yollu ve filigranlıdır. Cetvel ölçüleri, 170 x 103 mm'dir. Boş olan 1a varağında "İAE” kaşesi vardır. Yazıların başladığı $1 b$ ve $2 a$ varağındaki iki cetvel, siyah mürekkeple dışı kalın, içi ince çizgilidir ve çizgilerin arası bakır yaldızlıdır. Ayrıca 1b'nin başındaki yaklaşık 1/3'lük kısmın cetvel altındaki başlık kısmında, üzeri benekli kırmızı bordür ve bordürün içinde bir mihrabiye/serlevha vardır. Mihrabiye, bakır yaldız zemin üzerine beyaz, pembe mine çiçekli ve lacivert tığlıdır. 1b-2a'dan sonraki bütün varaklar (2b-138a), lal mürekkepli ve tek çizgi cetvellidir. ${ }^{161}$

Yazmanın hattı, harekeli iri nesihtir. Şema içeren farklı düzenlenmiş birkaç varak ${ }^{162}$ hariç tüm varaklar 13 satırlıdır. Bu satırlar, lal mürekkeple tahrir edilen başlıklar, tarihler, bazı menziller, yer isimleri, kişi isimleri ve diğer bazı kelimeler dışında siyah mürekkeple yazılmıştır. Vr. 26b'nin üçüncü satırından itibaren tüm varaklar harekelenmiştir. $3 b, 4 b, 5 b$ dışındaki varaklar, olması gerektiği gibi varağın " $b "$ yüzünün son satırının solunda ve cetvel dışında ayaklıdır. Bazı varaklarda derkenar vardır. ${ }^{163}$

Varak başlarına müstensih tarafından numara yazılmamıştır. Ancak sonradan, muhtemelen Rado tarafından- kurşun/sabit kalemle günümüz rakamları ile numaralandırma yapılmıştır. Ayrıca Rado aynı kalemle ilgili satırlarının hizasına $B N$ 'nın varak numaralarını eklemiş, önemli gördüğü ve $B N$ 'ye göre eksik olduğunu düşündügü yerleri de satırların boş yerine ve sayfaların kenarına Latin harfleriyle ya da rıka el yazısıyla not düşmüştür. ${ }^{164}$ 22b-23a ile 24b-25a varaklarında ise Osmanlı ordusu, Kırım Tatarları ve İsveç kuvvetlerinin Prut nehri kenarındaki bataklık civarında Rus ordusunu kuşatmasına dair çizeri belli olmayan basit, renkli bir harita vardır.

Müstensihi belli olmayan $R N$ 'nın istinsahı, 138a'nın son satırında lal mürekkeple yazılan "Kad vak 'a'l-ferā̆̆ min tahrīri hāzā'l-kitāb bi- 'avni'l-lāhi'l-Meliki'l-Vehhāb, fì 12 RA sene 1205" kaydiyla 19 Kasım 1790 tarihinde tamamlanmıştır. Bununla birlikte bu son satır, tarih hariç bizzat müellife ait olması gereken bir "te'lîfden ferâğ kaydı"dır. Sadece müellif tarafından yazılması gereken ferâğ kaydının (Abdulkadiroğlu, 1997, s. 545) geleneksel teamüle aykırı olarak istinsah edilmiş bir nüshaya istinsah tarihiyle yazılması, müstensihin bu konudaki bilgisizliğine ya da umursamazlığına

160 Ön kapak ile yazmanın ilk sayfası arasında, merhum Rado'nun nüsha ile ilgili kendi el yazısıyla yazdığı dört sayfa not ile Türk Dil Kurumu Başkanı Prof. Dr. Hasan Eren'e daktiloyla yazdığı iki sayfa mektup bulunmaktadır. Arka kapak ile yazmanın son sayfası arasında ise yine Rado'nun $B N$ ve $R N$ hakkında kısa bilgi verdiği biri el yazısı, diğeri daktilo ile yazığı iki sayfa not ile H. Eren'den gelen cevabî resmî yazı konulmuştur.

161 Arap harfli yazma eserlerde şeklî özellikler, kullanılan malzeme vb. terimler ve genel bilgi için bkz. Bilgin, 2013, s. 369373; U. Derman, 1987, s. 15-32; Sinan, 1987, s. 33-48; F. Ç. Derman, 1987, s. 63-68; Cumbur, 1987, s. 83-90; Binark, 1987, s. 91-108.

162 İlk sayfa olan 1b, 10 satırlı, 2a ise 13 satırlıdır. Menzillerin yazılı olduğu ve farklı düzenlendiği vr. 2b-6a ve 110b-111a'da ise sayılabilecek satır yoktur.

163 vr. 63a ve 70a.

164 Rado'nun not düştüğü varaklar: 1b, 26a, 40a, 41b, 48a-b, 53b, 58a, 61a, 62b, 72a-b, 76b, 81b, 86a'dır. 
hamledilmelidir. Müstensihin, kopya ettiği nüshada müellif ferâğ kaydı varsa onu aynen istinsah ettiği nüshaya yazması, altına da adının yer aldığı kendi istinsah kaydını koyması gerekirdi.

\subsubsection{Nüshanın Muhtevası}

Göynüklü Ahmed Efendi'nin eserinin dünyada bilinen iki nüshasından biri olan $R N, B N^{\prime}$ nda müellifin bizzat katıldığı 1711 Osmanlı-Rus Savaşı (Prut Seferi) ve İsveç Kralı Demirbaş Şarl'ın ülkesine dönmesi ile ilgili olayların yer aldığı vr. 215b/300b ile vr. 248a/332a arasındaki 34 varaklık küçük bir bölümü ihtiva etmektedir.

RN'ndaki vekâyi, 1b'nin başlığındaki Prut Seferi'nin başlangıç tarihi olarak kaydedilen 19 Şubat 1711 ile Veziriazam ve Serdarıekrem Baltacı Mehmed Paşa'nın tuğlarının Davutpaşa sahrasına dikildiği 9 Mart 1711 tarihiyle başlamakta ve 3 yıl 11 ay 6 gün sonra vr. 138a'da İsveç Kralı Demirbaş Şarl'ın Lehistan sınırından geçerek ülkesine doğru hareket ettiği 3 Aralık 1714 tarihiyle sona ermektedir.

$B N^{\prime}$ ye göre daha geç tarihli bir nüsha olan $R N^{\prime}$ nın imlâ ve fonetik özellikleri, Klâsik Osmanlı Türkçesi'nin Son Dönemi'den Yeni Osmanlı Türkçesi Dönemi'ne geçişin izlerini taşımaktadır. Ayrıca $B N$ ile karşılaştırıldığında, bazı kelimelerde ve cümlelerde eksiklikler ya da fazlalıklar olduğu görülmektedir.

Ancak iki nüsha arasındaki en önemli fark; Osmanlı ordusunun Prut nehri kıyısında Rus ordusunu kuşattığı sıralarda Osmanlı ordugâhına gönderilen Rus elçilerle yapılan görüşmelere ve bu görüşmelerde bazı Osmanlı ricâlinin ordunun üstün durumuna rağmen aşırı hoşgörülü ve alelacele barış yapmaya hevesli tutumlarının anlatıldığı varakların, $B N^{\prime}$ nda eksik olmasına rağmen $R N^{\prime}$ nda mevcut olmasıdır. ${ }^{165} B N$ 'ndaki bu eksik varaklar, restorasyon sırasında kaybolmuş ya da bir araştırmacı tarafından bilinçli bir şekilde yazmadan koparılmış olmalıdır. RN'nı görmeyen Kurat, söz konusu sayfaların bizzat Ahmed Efendi tarafından sonradan çıkarılmış olabileceğini belirtmiştir (1966, s. 263). Rado'ya göre ise bu eksik varaklar, büyük ihtimalle Rusların Osmanlı kuşatması sırasında düştüğü âciz ve trajik durumlardan etkilenen bir Rus tarafından bilinçli olarak yazmadan koparılmıştır (1987, s. 809). İlgili varaklarda Rus ordusunun perişan durumuna ve Osmanlı ordugâhına gelen Rus elçilerinin yalvararak barış istemelerine dair kayıtların bulunduğuna bakılırsa, Rado'nun iddiası gerçeğe en yakın ihtimal olarak kabul edilebilir.

\section{Sonuç}

Göynüklü Ahmed Efendi'nin eseri, yazma kütüphanelerinde sıklıkla tesadüf edilen edebî ve dinî mecmualardan farklı olarak yönetim, hukuk, maliye, din, edebiyat, astronomi, coğrafya, tarih, alternatif tıp (fitoterapi), büyü-tılsım, bilmece (muamma) ve fizyonomi gibi 12 ana konu altındaki 25 alt konuya ait yazıların derlendiği zengin konulu bir XVIII. yüzyıl mecmuası olarak dikkati çekmektedir.

Mecmuanın en ayırt edici özelliği ve önemi, Göynüklü Ahmed Efendi'nin bir Osmanlı maliye bürokratı olarak bizzat katıldığı Rus, Avusturya, Venedik ve İran

165 BN'nda söz konusu bölüme ait eksik olan 312a-b/227a-b, 314a-b/229a-b, 317a-b/232a-b, 318a-b/233a-b, 319a-b/234a-b varakları, $R N$ 'nda eksiksiz ve tam olarak $49 \mathrm{a}-53 \mathrm{~b}$ varaklarındadır. 
seferlerine ait gördüklerini ve duyduklarını kaleme aldığı "Tarih"tir (Göynüklü Ahmed Efendi Tarihi). Şahsî gözlem ve duyumlara dayandığı için o dönemin resmî tarih kaynaklarında olmayan bir çok ayrıntı ve bilginin yer aldığ 1 bu bölüm, XVIII. yüzyıl Osmanlı, Avusturya, Venedik, Rusya ve İran tarih araştırmaları için birincil kaynak durumundadır. Müellifin özellikle 1711 Osmanlı-Rus savaşının en kritik anlarındaki gelişmelere dair kayıtları, başka hiçbir kaynakta bulunmayan bilgileri ihtiva etmesi nedeniyle gerek XVIII. yüzyıl Osmanlı Rus ilişkilerinin gerekse Prut Seferi'nin karanlıkta kalmış olaylarını anlayabilmek için paha biçilemez değerdedir.

Bunun yanında Mecmua'da yer verilen konular incelendiğinde, müellifin şahsî beğenisi, zevki, eğilimleri, ilgi alanları, entelektüel düzeyi hakkında bir fikir edinmek de mümkün olabilmektedir. Söz konusu bilgiler çerçevesinde Ahmed Efendi'nin; sağlığına dikkat eden, işinde çalışkan ve sabırlı, inançlı ve ibadetlerine özen gösteren, tasavvufa âşina, ebced vefk, cifr, tılsım gibi dinin metafizik boyutuna meraklı, astronomi ve astrolojiyi önemseyen, az çok karşı cinsi tanımanın gerekliliğine inanan ve tabii katıldığı savaşlara ait tanıklıklarını tarihe mal etmek isteyen bir devlet adamı olduğu söylenebilir. Onun mecmuasını vücuda getirme yolundaki azim ve çabası ise birikim ve tanıklıklarına ait kayıtları sonraki kuşaklara aktarma hususunda sorumluluk hissettiğini göstermektedir.

Tüm bu bilgiler çerçevesinde nüshaları, fizikî özellikleri ve muhtevası ile tanıtmaya çalıştığımız Göynüklü Ahmed Efendi'nin Mecmuası, XVII-XVIII. yüzyıl Osmanlı idarî, iktisadi, hukukî ve siyasî tarihi üzerine araştırma yapanlar için olduğu kadar ilahiyat, edebiyat, coğrafya, astronomi, alternatif tıp, büyü-tılsım, fizyonomi gibi farklı disiplinlerde çalışanların da istifade edebileceği bir kaynak eser mahiyetindedir.

\section{Summary}

Some Ottoman Scientists and Statesmen had been penned some texts which were named "Mecmua" on different topics as combining religious and non-religious writings. Concordantly, the Mecmua which was covering some notes and writings in religious and non-religious works, Göynüklü Ahmed Efendi, who was a Ottoman finance bureaucrat, is examined in this study.

It has been known that there are two versions of Mecmua. One of them, Berlin version $(B N)$, is in the Berlin State Library (Staatsbibliothek zu Berlin) in Germany as the other one, Rado version $(R N)$, is in the Ottoman Studies and Şevket Rado Manuscripts Library in İstanbul. In the study, firstly $B N$ and $R N$ are introduced, afterwards the physical characteristics of the manuscripts are handled. The pages of the manuscript are reorganized, because the related things or events in the manuscript, which were penned by the author, lost its sequence due to the course of time. Each is depicted by its detailed physical aspects and content. The more comprehensive one is $B N$, with 372 pages. Having only 34 pages, $R N$, which was copied later, involves a small part of $B N$. RN covers some events related with the 1711 Russo-Ottoman War (Pruth Campaign), which the author appeared in person, and the return to his country of Charles XII, King of Sweden. In the years following the author's death, on the BN, some notes have been deducted and some amendments were made by the owner of the manuscript while for nothing had been done except the notes which were deducted by 
Şevket Rado who was the last owner of the copy.

Unlike the literary and religious-themed Mecmuas, which are common in the manuscript libraries, in the $B N$, there are 25 subheadings under 12 main topics, such as literature, theology, management, law, finance, astronomy, geography, history, alternative medicine, magic-amulet, riddles and physiognomy which are determined by the author according to his personal characteristics such as appreciation, delight, trend, interests and intellectual level. After these issues are examined, it can be concluded that Ahmed Efendi was a statesman who was caring his health, assiduous and patience in the business, familiar with Sufism, curious to the astronomy, astrology and the metaphysical aspect of the religion such as abjad, vefk, cifr and talisman while who was believing in the necessity to understand the opposite sex more or less as well. His dedicated efforts to bring into being the Mecmua is a hint to indicate his responsibility for handing down his records related with his testimonies and knowledge to the next generations.

In the Mecmua, some vefks and talismans, location of the cities, routes and finical formulas are depicted by the simple drawings or nested circles. Besides, both copies cover a map which gives the details of the siege of the Russian army by the Ottomans on the banks of the Pruth River.

Records about the Pruth, Mora, Habsburg and Iran campaigns which were taken by himself, author Ahmed Efendi in the Mecmua, differentiates it and gives prominence among its counterparts. $R N$ is unique and substantial, because its eight pages cover the Ahmed Efendi's own observations about the mistakes which were done by the Ottomans during truce negotiations for the 1711 Russo-Ottoman War and the distraught manner of the Russians as $B N$ missing these pages.

In the context of all mentioned above, the Mecmua of Ahmed Efendi can be considered as a primary source for the ones who are conducting the academic studies on finance, law and diplomatic history of Ottomans in the $17^{\text {th }}$ and $18^{\text {th }}$ centuries as well as on the different disciplines such as theology, literature, geography, astronomy, alternative medicine, magic-amulet and physiognomy. 


\section{KAYNAKÇA}

Abdulkadiroğlu, A. (1997). Edebiyatta metodoloji açısından elyazmaları ve nâdir eserler üzerine notlar I. Kültürümüzden Esintiler. 527-556.

Ahmed Vâssf Efendi (1219). Mehâsinü'l-âsâr ve hakâiyu'l-ahbâr. (C. 1). İstanbul.

Aksoyak, İ. H. (2002). Nâbî'nin tuhfetü'l-harameyn'inin Edirneli Nâtık'in tuhfetü'l-harameyn'ine etkisi: hikâyeler, gelenekler, inanışlar. Milli Folklor. 24(95). 9-22.

Algül, H. (2004). El-mevâhibü'l-ledünniyye". İslâm Ansiklopedisi (C. 29, s. 421). İstanbul: Türkiye Diyanet Vakf1 Yay.

Ateș, İ. (1978). Şam Ümeyye camii ve vakfiyesi", Vakıflar Dergisi, 12, 27-90.

Atıl, E. (1999). Levni ve surname-bir Osmanl şenliğinin öyküsü. İstanbul: Koçbank.

Aydemir, Y. (2007). Metin neşrinde mecmuaların rolü ve karşılaşlan problemler. Turkish Studies/Türkoloji Araştırmaları, 2(3). 122-137.

Babinger, F. (2000). Osmanlı tarih yazarları ve eserleri, (C. Üçok, Çev.). Ankara: Kültür Bakanlığı Yay. Bilgin, O. (2013). Yazma. İslâm Ansiklopedisi (C. 43, s. 369-373). İstanbul: Türkiye Diyanet Vakfı Yay.

Binark, İ. (1987). Türk kitapçılık târihinde cilt sanatı. T. Gülensoy (Ed.), Fırat Üniversitesi Yazma Eserler Sempozyumu Bildirileri içinde (s. 91-108). Elazığ: Fırat Üniversitesi Yay.

Cumbur, M. (1987). Yazma eserlerde kullanılan kâğı̆t ve özellikleri. T. Gülensoy (Ed.), Furat Üniversitesi Yazma Eserler Sempozyumu Bildirileri içinde (s. 83-90). Elazı̆̆: Fırat Üniversitesi Yay.

Çetin, A. (1992). Bir bâbıâlî kâtibinin not defterinden I. Türk Dünyası Araştırmaları Vakfı Türk Dünyası Tarih Dergisi. 72. 41-47.

Çetin, A. (1993). Bir bâbiâlî kâtibinin not defterinden II. Türk Dünyası Araştırmaları Vakfı Türk Dünyası Tarih Dergisi. 73. 33-39.

Çolak, S. (1985). Aziz efendi'nin risalesine göre, 17. yüzyılda Osmanlı merkez ordusunun durumu. History Studies-International Journal of History. 2(2). 101-112.

Çolak, S. (1999). Die bedeutung des geschichtsschreibers Ahmed b. Mahmud und seines werkes târih-i Göynüklü als quelle für die geschichte des Osmanischen reiches im 18. Jahrhundert. Berlin: Mensch\&Busch.

Çolak, S. (2003). XVIII. yüzyıl Osmanlı tarih yazıcılarından hazine-i birûn kâtibi Ahmed bin Mahmud'un hayati. Belleten. 68(250). 853-865.

Derman, Ç. F. (1987). Yazma eserlerde tezhib sanatı. T. Gülensoy (Ed.), Fırat Üniversitesi Yazma Eserler Sempozyumu Bildirileri içinde (s. 63-68). Elazığ: Fırat Üniversitesi Yay.

Derman, U. M. (1987). Yazma eserlerde kullanılan alet ve malzemeye dair. Firat Üniversitesi Yazma Eserler Sempozyumu Bildirileri içinde (s. 15-32). Elazığ: Fırat Üniversitesi Yay.

Erdoğan, K. (2004). Bosnalı Hasan Kâimî ve divanı'nın Manisa nüshası. Türk Kültüurü ve Hacı Bektaş Velî Araşttrma Dergisi. 31. 257-269.

Ertaş, Y. M. (2007). Sultanın ordusu. İstanbul: Yeditepe Yay.

Fayda, M. (1988). Abdullah b. Selâm. İslâm Ansiklopedisi (C. 1: 134-135). İstanbul: Türkiye Diyanet Vakfı Yay.

Flemming, B. (1968). Verzeichnis der orientalischen handschriften in Deutschland-Türkische handschriften (Band XIIL 1). Weisbaden: Franz Steiner Verlag GMHB.

Gıynaş, K. A. (2011). Şiir mecmuaları hakkında yapılan çalı̧̧malar bibliyografyası. Selçuk Üniversitesi Edebiyat Fakültesi Dergisi, 25, 245-260.

Hazîne-i Bîrûn Kâtibi Ahmed bin Mahmûd Efendi. Mecmū'a. Staatsbibliothek zu Berlin. Preußischer Kulturbesitz, Orientabteilung, Ms. or. quart. 1209, 1a-371b.

Hazîne-İ Bîrûn Kâtibi Ahmed Bin Mahmûd Efendi. Mecmū'a. İstanbul Araştırmaları Enstitüsü Yazma Eserler Kütüphanesi, Şevket Rado Yazmaları, ŞR000614, 1b-138a.

İpşirli, M. (1991). Ayn Ali Efendi. İslâm ansiklopedisi (C. 4, s. 258-259). İstanbul: Türkiye Diyanet Vakfı Yay.

İpşirli, M. (2006). Bolevî Mustafa Efendi. İslâm ansiklopedisi (C. 31, s. 295-296). İstanbul: Türkiye Diyanet Vakfı Yay.

İpşirli, M. (2006). Naîmâ. İslâm ansiklopedisi (C. 32, s. 316-318). İstanbul: Türkiye Diyanet Vakfı Yay.

İstanbul Araştırmaları Enstitüsü (2014). İstanbul araştırmaları enstitüsü yazma eserler kataloğu, 2. G. Kut, Z. Toska, F. Büyükkarcı Yılmaz, T. Gençtürk Demircioğlu \& A. Atik (Haz.), İstanbul. 
Kandemir, Y. M. (1995). Fezâil. İslâm ansiklopedisi (C. 12, s. 529-531) İstanbul: Türkiye Diyanet Vakfı Yay.

Kut, G. (1986). Mecmualar. Türk dili ve edebiyatı ansiklopedisi (C. 6, s. 170-173). İstanbul: Dergâh Yay.

Kut, G. (1988). Yazmalar arasında II. İ. Erünsal, C. Ferrard \& C. Woodhead (Ed.), Osmanlı araştırmaları (The Journal of Ottoman Studies) içinde (C. VII-VIII, s. 181-198). İstanbul: İSAM Yay.

Kaplan, D. (2010 Güz). Ehl-i beyt'in gizli ilmi: Hz. Ali'ye nispet edilen kitâb-1 Ali (sahîfe-câmia) cefr ve mushaf-1 Fâtıma hakkında bir inceleme. Selçuk Üniversitesi İlahiyat Fakültesi Dergisi, 30, 7592.

Kurat, A. N. (1943). İsveç kralı XII. Karl'ın Türkiye'de kaldığı zamana ait metinler ve vesikalar-ekler 1. Ankara Üniversitesi Dil ve Tarih-Coğrafya Fakültesi Yay.

Kurat, A. N. (1951, 1953). Prut seferi ve barışı, 1-2. Ankara Üniversitesi Dil ve Tarih-Coğrafya Fakültesi Yay.

Kurat, A. N. (1966). Hazine-i bîrun kâtibi Ahmed bin Mahmud'un (1123-1711-Prut) seferine ait defteri. Ankara Üniversitesi Dil ve Tarih-Coğrafya Fakültesi Dergisi, 4(6-7), 357-426.

Levent, A. S. (1984). Türk edebiyatı tarihi-giriş I. Ankara: Türk Tarih Kurumu Yay.

Mehmed Süreyyâ (1301). Sicill-i Osmânî. N. Akbayar (Ed.), (C. 4). İstanbul: Tarih Vakfı Yurt Yay.

Mehmed Süreyyâ (1308). Sicill-i Osmânî yâhûd tezkire-i meşâhir-i Osmâniyye,.(C. I). İstanbul: Matbaa-i Âmire.

Murphey, R. (1985). Kanûn-nâme-i sultân̂̂ li Azîz efendi. Cambridge: Harvard Üniversitesi Yay.

OCAK, A. Y. (1994). Ebü'l-Vefâ el-Bağdâdî, İslâm ansiklopedisi (C. 10, s. 347-348) İstanbul: Türkiye Diyanet Vakfı Yay.

Öz, T. (1942 Ağustos). Yerköy mükâlemelerinde murahhaslar için gönderilen büyüler. Tarih Vesikaları, II(8), 101-103.

Özcan, A. (1991). Bâb-ı seraskerî. İslâm ansiklopedisi (C. 4, s. 364-365) İstanbul: Türkiye Diyanet Vakfı Yay.

Özen E. M. (1985). Yazma kitap sanatları sözlü̈̆̈̈̈. İstanbul Üniversitesi Yay.

Pala, İ. (2014 Eylül). Ansiklopedik divân şiiri sözlüğ̈̈̈. İstanbul: Kapı Yay.

Rado, Ş. (1987). Hazine-i bîrun kâtibi Ahmed bin Mahmud efendinin tuttuğu Prut seferine ait defterden koparılan sahifelerde neler vard1?, Belleten, 50(198), 804-827.

Sahillioğlu, H. (1967). Sıvış yılı buhranları. İstanbul Üniversitesi İktisat Fakültesi Mecmuası, 27(1-2), 75111.

Sargut, C. (2009). İman ve küfür-Bakara 1. İstanbul: Nefes Yay.

Şemseddîn Sâmî, (1318). Kâmûsıı Türkî. (C 1-2). Dersa'âdet: Ahmed Cevdet (Yay.)

Şenel, A. (2001). Kastallânî, Ahmed b. Muhammed. İslâm ansiklopedisi (C. 24, s. 583-584). İstanbul: Türkiye Diyanet Vakfı Yay.

Tezcan, H. (2011 Ocak). Topkapı sarayı müzesi koleksiyonundan tılsımlı gömlekler. İstanbul: Timaş Yay. Topkapı Sarayı Müzesi Kütüphanesi. E. 3809/2-655/19.

Uzun, M. İ. (1994). Ebced. İslâm ansiklopedisi (C. 10, s. 68-70). İstanbul: Türkiye Diyanet Vakfı Yay.

Uzun, M. İ. (2003). Mecmua. İslâm ansiklopedisi, (C. 28, s. 265-268). İstanbul: Türkiye Diyanet Vakfı Yay.

Uzun, M. İ. (2006). Nahîfî. İslâm ansiklopedisi (C. 32, s. 297-299). İstanbul: Türkiye Diyanet Vakfı Yay. Uzunçarşılı, İ. H. (1982). Osmanlı tarihi. (C. IV/1). Ankara: Türk Tarih Kurumu Yay.

Yavuz, Y. Ş. (1991). Âşûrâ. İslâm ansiklopedisi (C. 4, s. 24-26). İstanbul: Türkiye Diyanet Vakfı Yay.

Yıldız, H. (2019). Göynüklü bir tarih yazıcısı: şıkk-ı sani defterdarı ve hazine-i birun kâtibi Ahmed bin Mahmud efendi. Bolu Abant İzzet Baysal Üniversitesi Sosyal Bilimler Enstitüsü Dergisi, 19(3), 843-863.

Yılmaz, K. (2017). Türk İslam edebiyatında faziletnameler ve Mekke, Medine, Kudüs, Şam üzerine yazılmış manzum bir faziletname. Bilecik Şeyh Edebali Üniversitesi Sosyal Bilimler Enstitüsü Dergisi, 2(2), 366-381. 


\section{İnternet:}

Ahmed b. Mahmud. (t.y.). Mecmua. http://orient-digital.staatsbibliothek-berlin.de (http://orientdigital.staatsbibliothek-

berlin.de/servlets/solr/select?q=\%2Bcategory.top $\% 3 \mathrm{~A} \% 22$ IslamHS class $00000009 \% 3 \mathrm{ALAN}$ G0003\%22+\%2BobjectType \%3Aislamhs\&fl=id\%2CreturnId\&sort=mymss ihsinvent+asc\&XS L.Style=browse\&origrows $=50 \&$ version $=4.5 \&$ mask $=$ islamhs class $00000009 . x m l \% 3 F X S L . l a s t$ Page.SESSION\%3D\%2Fislamhs class_00000009.xml\%23open\%5B\%5D\&start=3036\&rows=1. Erişim tarihi: 14.12 .2019 .

Hatipoğlu, N. (2016, 24 Mart). Yedi Ayetler ve Hikmetleri.
https://www.youtube.com/watch?v=N5drmmPFvmw. 